\title{
Phylogeny of the family Trogidae (Coleoptera: Scarabaeoidea) inferred from mitochondrial and nuclear ribosomal DNA sequence data
}

\author{
W E R N R P. STR ÜMPHER ${ }^{1,2}$, C ATHER I N L . S O LE ${ }^{2}$, M A R T N H. \\ V I L L E T ${ }^{1}$ and C L A R K E . S C H O L T Z \\ ${ }^{1}$ Department of Zoology and Entomology, Rhodes University, Grahamstown, South Africa and ${ }^{2}$ Scarab Research Group, Department \\ of Zoology \& Entomology, University of Pretoria, Pretoria, South Africa
}

\begin{abstract}
Trogidae constitute a monophyletic and biologically unique family within Scarabaeoidea, being the only keratinophagous group in the superfamily. Traditionally, the family has been divided into three distinctive genera, Polynoncus Burmeister, Omorgus Erichson and Trox Fabricius. Although the taxonomy of the group is relatively well studied, changes to the existing classification have recently been proposed and the family as currently constituted has not been subjected to phylogenetic analyses. Here we present a molecular phylogeny for this cosmopolitan family based on three partially sequenced gene regions: $16 \mathrm{~S}$ rRNA, 18S rRNA and 28S rRNA (domain 2). Included in the analyses are representatives belonging to four of the five extant genera (and three of the four subgenera) from all major zoogeographic regions, representing about $20 \%$ of the known trogid species diversity in the family. Phylogenetic analyses performed included parsimony and Bayesian inference. We deduce their historical biogeography by using trogid fossils as calibration points for divergence estimates. Our analyses resolved relationships between and within genera and subgenera that are largely congruent with existing phylogeny hypotheses based on morphological data. We recovered four well-supported radiations: Polynoncus, Omorgus, Holarctic Trox and African Phoberus MacLeay. On the basis of this study, it is proposed that taxonomic changes to the generic classification of the family be made. The subgenera Trox and Phoberus should be elevated to genera to include the Holarctic and all the Afrotropical species, respectively, and Afromorgus returned to subgeneric rank. Estimates of divergence time are consistent with a Pangaean origin of the family in the Early Jurassic. The subsequent diversification of the major lineages is largely attributed to the break-up of Pangaea and Gondwana in the Middle Jurassic and early Late Cretaceous, respectively.
\end{abstract}

\section{Introduction}

Trogidae MacLeay (Coleoptera: Scarabaeoidea) comprise approximately 330 species worldwide (Scholtz, 1982; Smith, 2003; Pittino, 2006; Zidek, 2013). This family is well known for its remarkable feeding specialization; all known species (adults and larvae) feed almost exclusively on keratin and are the only members of the Scarabaeoidea capable of digesting it (Scholtz,

Correspondence: Werner P. Strümpher, Scarab Research Group, Department of Zoology \& Entomology, University of Pretoria, Private Bag X 20, Hatfield 0028, Pretoria, South Africa. E-mail: wstrumpher@zoology.up.ac.za 1986a). They primarily inhabit the temperate and arid/savannah regions of the world. Africa and Eurasia have the richest fauna with about 100 species each, followed by Australia (55 species), and South and North America, with around 50 species each (Scholtz, 1982, 1986a,1986b, 1990; Pittino, 2006; Table 1). The group is taxonomically well studied and the fauna of each of the zoogeographical regions has been revised (Balthasar, 1936; Haaf, 1954a,1954b; Vaurie, 1955, 1962; Scholtz, 1980, 1982, 1986b, 1990; Pittino, 1983, 1985; Scholtz et al., 2007; Zidek, 2013).

Much of our understanding of generic-level relationships within Trogidae is the result of Scholtz's (1986a) phylogenetic 
Table 1. Classification and biogeographical distribution of the family Trogidae.

\begin{tabular}{|c|c|c|c|c|}
\hline Genus & Subgenus & Region & Distribution & \# spp. \\
\hline \multicolumn{5}{|l|}{ Troginae } \\
\hline Trox & Trox & Palaearctic & $\begin{array}{c}\text { Europe/Asia/ } \\
\text { Oriental }\end{array}$ & 77 \\
\hline Trox & Trox & Nearctic & North America & 28 \\
\hline Trox & Trox-Phoberus & Afrotropical & $\begin{array}{l}\text { Sub-Saharan } \\
\text { Africa, } \\
\text { Madagascar }\end{array}$ & 40 \\
\hline $\begin{array}{l}\text { Madagatrox } \\
\text { Omorginae }\end{array}$ & - & Afrotropical & Madagascar & 1 \\
\hline Omorgus & Omorgus & Australasian & $\begin{array}{l}\text { Australia, } \\
\text { Indonesia, Asia }\end{array}$ & 57 \\
\hline Omorgus & Omorgus & Nearctic & North America & 20 \\
\hline Omorgus & Omorgus & Neotropical & South America & 14 \\
\hline Omorgus & Haroldomorgus & Neotropical & South America & 1 \\
\hline Afromorgus & - & Afro-Oriental & $\begin{array}{r}\text { Africa, Arabia, } \\
\text { Orient, Asia }\end{array}$ & 54 \\
\hline Polynoncus & - & Neotropical & South America & 34 \\
\hline
\end{tabular}

study, which was the first attempt to infer relationships among and within genera based on synapomorphic characters. The resulting phylogenetic classification, which has remained relatively stable for the last three decades, divided the family into two distinct lineages, a basal Trox Fabricius lineage (with two subgenera, Trox s.s. and Phoberus MacLeay) and a derived lineage consisting of the genera Polynoncus Burmeister and Omorgus Erichson (with tree subgenera Omorgus s.s., Haroldomorgus Scholtz and Afromorgus Scholtz). Phylogenetic studies that followed Scholtz (1986a) supported these findings, and demonstrated that: (i) Trogidae is a monophyletic group within the superfamily Scarabaeoidea; and (ii) monophyletic genera can be defined on the basis of both adult and larval synapomorphic character states (D'Hotmann \& Scholtz, 1990; Nel
\& Scholtz, 1990; Scholtz \& Peck, 1990; Scholtz, 1991, 1993; Browne et al., 1993; Browne \& Scholtz, 1995, 1999; Grebennikov \& Scholtz, 2004) (Fig. 1).

Subsequent authors have proposed changes to Scholtz's (1986a) classification. Nikolajev (2005) split Trogidae into two subfamilies: Troginae MacLeay containing the genus Trox, and Omorginae Nikolajev comprising the genera Omorgus and Polynoncus. Pittino (2006) elevated the subgenus Afromorgus to generic status. A new genus from Madagascar, Madagatrox Pittino, was recently described (Pittino, 2010). There are currently five valid extant genera in Trogidae: Trox (with two subgenera, Trox and Phoberus), Omorgus (with two subgenera, Omorgus and Haroldomorgus), Afromorgus, Polynoncus, and Madagatrox. However, the family as currently constituted have yet to receive any formal phylogenetic analyses.

Trogidae have long been considered to represent a plesiomorphic group within the Scarabaeoidea, whose origin extends back to the Upper Jurassic/Lower Cretaceous (Scholtz, 1986a; Scholtz \& Chown, 1995). In Scholtz's (1986a) attempt to resolve the phylogenetic relationships within the family, based on shared derived morphological characters and current distribution patterns, he hypothesized that trogids evolved in central Pangaea, prior to the break-up of the supercontinent that formed Laurasia and Gondwana. Following the break-up of Pangaea, the lineage that eventually gave rise to Trox was restricted to Laurasia, and the ancestral Omorgus lineages to Gondwana. The ancestral Omorgus and Polynoncus lineages radiated on the Gondwana continents, while the Trox lineage radiated in the Holarctic and later another derived lineage (Phoberus) dispersed into Africa, along the temperate eastern highland mountain faunal exchange route. The recent discovery of Mesozoic fossils of Trogidae has confirmed the long-standing view that the family represents an ancient group of beetles within Scarabaeoidea (Browne \& Scholtz, 1999; see Krell, 2007; Nikolajev, 2009 for fossil data). These fossil records also predate the only current (molecular) estimate for the divergence of the family, which is

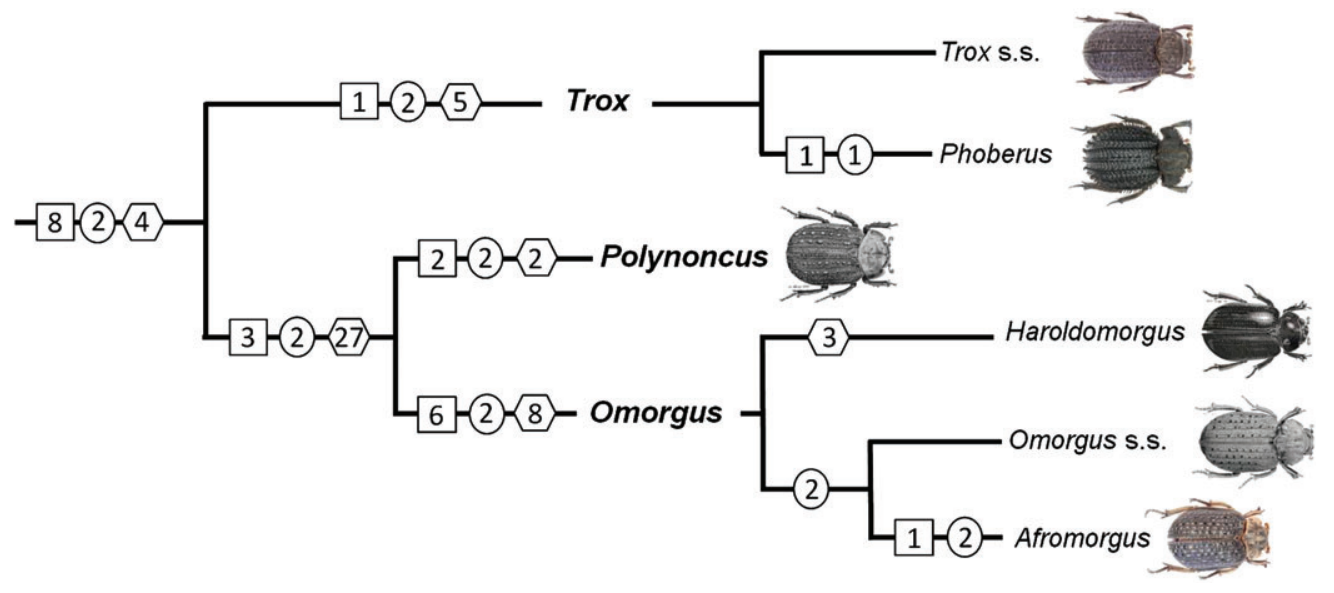

Fig. 1. Phylogram of the Trogidae genera and subgenera based on larval (boxes), adult (circles) and hind wing (hexagons) synapomorphic characters. Numbers represent the number of characters that unite each node. For details on larval characters, see Scholtz \& Peck (1990), Scholtz (1993) and Grebennikov \& Scholtz (2004); for adult (excluding hind wing) characters, see Scholtz (1986a) and Browne \& Scholtz (1999); for hind wing characters, see Browne et al. (1993) and Browne \& Scholtz (1995). Images depict the type species of the genus or subgenus. 
121.4 million years ago (Ma; McKenna \& Farrell, 2009). Furthermore, discovery of Cretaceous-aged fossils (98-144 Ma) ascribed to Trox from modern north-east Asia (Nikolajev, 2007, 2009) lends support to the proposed Laurasian origin for this lineage (Scholtz, 1986a).

The aim of this study is to investigate the phylogenetic relationships of the world genera and subgenera based on partial DNA sequences of three ribosomal gene regions (two nuclear and one mitochondrial). Secondly, we deduce their historical biogeography by estimating the ages of major divergence events using fossil data.

\section{Materials and methods}

Sampling, amplification, sequencing and processing

of sequences

Specimens preserved in ethanol were obtained from all the major zoogeographic regions (Table S1), representing approximately $20 \%$ of the known trogid species diversity. Four of the five extant genera (and three of the four subgenera) in the family are represented in the ingroup sample. Only the rare, monotypic subgenus Haroldomorgus Scholtz and the monotypic genus Madagatrox are not included in our phylogeny, as specimens suitable for DNA extraction could not be obtained. Studies on the higher classification of Coleoptera and Scarabaeoidea indicate that Bolboceratidae Scholtz \& Browne, Lucanidae Latreille and Trogidae are closely related clades within the superfamily Scarabaeoidea (Browne \& Scholtz, 1999; Smith et al., 2006; Hunt et al., 2007; Lawrence et al., 2011). Based on these results, representative species belonging to the families Bolboceratidae and Lucanidae were selected as suitable outgroups.

Collected individuals were identified, catalogued and stored for further data analysis. Specimens are deposited at the Department of Zoology and Entomology, University of Pretoria, South Africa (UPSA).

Total genomic DNA was extracted from all individuals using the Roche High Pure PCR Template Preparation Kit (Roche Diagnostics, Penzberg, Germany). We amplified the nuclear genes $18 \mathrm{~S}$ rDNA (18S) and 28S rDNA domain 2 (28S) and the mitochondrial gene 16S rDNA (16S) using previously reported primer sequences and a newly designed primer for $28 \mathrm{~S}$ (Table $\mathrm{S} 2$ ). The $16 \mathrm{~S}$ and $18 \mathrm{~S}$ genes were amplified using the polymerase chain reactions (PCRs) performed in a final volume of $50 \mu \mathrm{L}$. PCR reaction mixtures contained $2.5 \mathrm{mM} \mathrm{MgCl}_{2}$, 20 pmol of each primer, $10 \mathrm{~mm}$ dNTPs, $1 \times$ PCR buffer, in the presence of one unit of TaqDNA polymerase (Super-Therm ${ }^{\circledR}$ DNA polymerase, Separation Scientific SA (PTY) LTD, South Africa) and 50-100 ng of genomic DNA template. For 28S, Emerald Amp ${ }^{\circledR}$ MAX HS PCRMastermix (Takara Bio Inc., Otsu, Shiga, Japan) was used. Different cycling parameters were implemented for each gene (Table S3). Successful amplifications were purified using the Roche High Pure Product Purification Kit (Roche Diagnostics) following the manufacturer's instructions.

To obtain DNA sequences, the cycle sequencing reactions were carried out in both directions using the BigDye ${ }^{\circledR}$
Terminator v3.1 Cycle Sequencing kit (Applied Biosystems, Foster City, CA, USA). Cycle sequencing products were precipitated using a standard sodium acetate/ethanol precipitation protocol. All sequences generated were viewed, assembled and edited in CLC BIO MAIN WORKBENCH version 5.5 (developed by CLC Bio, http://www.clcbio.com). New sequences (Table S1) were submitted to GenBank. Partial 16S RNA sequences of two more Trox species, Trox uenoi (Accession no.AB178316) and one unidentified species (accession no. EF487978) retrieved from GenBank, were included in the analysis.

\section{Alignment}

Processed sequences for each of the different gene regions (16S, 28S domain 2, 18S) were aligned based on secondary structure using RNASALSA version 0.8.1.win32 (Stocsits et al., 2009). The program uses both secondary structure information for adjusting and refining sequence alignments and sequence information contained in the alignments to refine predictions of structure (Stocsits et al., 2009). To initialize the analytical process, RNASALSA requires both an initial alignment of homologous RNA sequences and structural constraints (secondary structure predictions) for a single sequence to guide the alignment process.

The input alignments, for each gene region, were produced using MAFFT (Katoh \& Toh, 2008). For 28S, structural alignment was performed based on the secondary structure of the $28 \mathrm{~S}$ sequence of Apis mellifera (Gillespie et al., 2006). The structural constraints for $18 \mathrm{~S}$ (Trox rudebecki - accession number AY745581) and 16S (T. uenoi - accession number AB178316) were predicted using the RNAfold server (Hofacker, 2003; Gruber et al., 2008). The server predicts minimum free energy (MFE) structures and base pair probabilities of single-stranded RNA or DNA sequences. Runs were initiated with default parameter settings for substitution cost, gap penalties and base-pairing occurrence stringencies, except for two stringency settings (-s1, -s 3 ) which were set to 0.51 . RNASALSA constructs a final multiple sequence alignment together with a consensus structure. For a detailed discussion of RNASALSA, refer to Stocsits et al. (2009). The alignments for the three partial sequences, including information on their consensus secondary structures, were concatenated into a supermatrix using the program FASCONCAT version 1.0 (Kück \& Meusemann, 2010a,b).

\section{Evaluating the general structure and potential conflict in alignments}

We constructed a neighbour-network of the individual and the concatenated alignments using the program SPLITSTREE 4 (Huson \& Bryant, 2006). Neighbour-net analyses can be used to visualize conflicting signal (ambiguities) in the data or alternative phylogenetic histories through a splits graph, and help to assess the tree-likeness (congruence) of the data, independently of tree reconstruction techniques (Huson \& Bryant, 2006; Wägele \& Mayer, 2007). Networks were based on 
uncorrected $p$-distances. Parsimony uninformative sites were excluded. Bootstrap support values calculated were based on 1000 replicates.

\section{Phylogenetic analysis}

Analyses were conducted using maximum parsimony and Bayesian inference for the combined dataset. The parsimony analysis was implemented in PAUP*4.010b (Swofford, 2003) with the following heuristic search setting: all characters were equally weighted and unordered, gaps were treated as missing data and uninformative sites excluded; starting tree obtained via stepwise addition with random addition of sequences with ten replicates; branch-swapping = tree-bisection-reconnection; initial 'maxtrees' set to 200 with automatic increase by 100 and with 'MulTrees' option in effect. Where more than one most parsimonious tree was obtained, a strict consensus tree was calculated. Bootstrap support values (Felsenstein, 1985) calculated were based on 1000 replicates.

Bayesian analyses were performed in MRBAYES v3.1.2 (Ronquist \& Huelsenbeck, 2003) and in PHASE v2.0 (Jow et al., 2002; Gowri-Shankar \& Jow, 2006). Both programs can simultaneously analyse partitioned datasets using both conventional DNA models and mixed RNA/DNA substitution models.

Analysis in MRBAYES was performed using the GTR $+\mathrm{G}$ model for $16 \mathrm{~S}$ and $28 \mathrm{~S}$ and the $\mathrm{K} 80+\mathrm{I}+\mathrm{G}$ model for $18 \mathrm{~S}$. The appropriate model of nucleotide evolution was estimated in JMODELTEST (Posada, 2008) under the Akaike information criterion (model parameters are summarized in Table S4). The data set was partitioned into three gene regions. Parameters for the different partitions were unlinked to obtain separate parameter estimates for each gene and the rate prior was set to variable. Flat Dirichlet priors were used in all analyses. Bayesian analyses were conducted by simultaneously running two Monte Carlo Markov (MCMC) chains for 15 million iterations. Trees were sampled every 200th iteration. The first 15000 trees (20\%) sampled were discarded as burn-in.

Analysis in PHASE was performed using the RNA7D + dG6 + I model (Tillier \& Collins, 1998) for paired nucleotides. Although applied here empirically, as the testing of RNA models is beyond the scope of this study, the RNA7D model is a biologically plausible model for the evolution of paired nucleotide sites (Voigt et al., 2008; Elven et al., 2010; Gazave et al., 2010). For the unpaired regions (loops), we used the general time reversible model $(\mathrm{REV}+\mathrm{dG6}+\mathrm{I})$. For further details of RNA-specific models, see Savill et al. (2001) and Jow et al. (2002). Phylogenetic trees were constructed using the mcmcphase module from the PHASE package with default values for priors and other $m c m c$ parameters. The final analysis was run for 30 million iterations, and trees were sampled every 200 iterations. The first three million iterations were discarded as burn-in, which was a sufficient period for log-likelihood values and model parameters to reach stabilization. The module mcmcsummarize generated the consensus trees and all of the relevant statistics, including branch lengths and clade support for each node. Optimal branch lengths were calculated (as suggested in the PHASE manual) by running an additional mcmcphase analysis (five million generations) under the same models as the 30 million generation mcmcphase run. We used the consensus tree from the final analyses ( 30 million generations) to fix the tree topology (with topology proposals turned off) and all other parameters left unchanged. To determine if all runs from the mcmcphase analyses reached the same stationary distribution, output files from the mcmcphase analyses were formatted, using a modified version of the Perl script phase2tracer.pl (original file available from http://hymenoptera.tamu.edu/rna/download.php) to create readable input files for TRACER 1.5 (Rambaut \& Drummond, 2007). We repeated the analysis three times from random starting seeds, and compared the resulting topologies and posterior probabilities.

For comparative purposes, we tested a 16-state RNA model in MRBAYES, which implements a 16-state RNA stem substitution model (Schöniger \& von Haeseler, 1994). This 16-state RNA model considers all possible base pairs as characters and assumes that compensatory base exchanges result from at least two substitution events (Voigt et al., 2008). The concatenated dataset was partitioned into loop and stem regions for $16 \mathrm{~S}, 18 \mathrm{~S}$ and $28 \mathrm{~S}$. The covarian model was implemented for the paired nucleotides (stems). For the loop regions, a GTR $+\mathrm{I}+\mathrm{G}$ (a six-state single-nucleotide model) was implemented. Parameters for the different partitions were unlinked to obtain separate parameter estimates for each gene and the rate prior was set to variable. Flat Dirichlet priors were used in all analyses. Posterior probabilities were calculated by simultaneously running two Markov chains for five million iterations. Trees were sampled every 200 iterations, and the first 5000 trees (20\%) sampled were discarded as burn-in.

To evaluate the performance of the Markov chains, from MRBAYES analyses, we used the program AWTY (are we there yet?) (Nylander et al., 2008) to assess the convergence rates of posterior probabilities and branch lengths from sampled trees. The program TRACER was used to monitor parameter stabilization [via inspection of estimated sample size (ESS) and graphical plots of parameter sampling]. FIGTREE v1.3.1 (Rambaut, 2009) was used to view all tree topologies. All Bayesian analyses were carried out on the Bioportal facility (http://www.bioportal.uio.no) at the University of Oslo, Norway.

\section{Divergence analysis}

We estimated the node ages for the major lineage-splitting events within Trogidae using the program BEAST v.1.6.2 (Drummond \& Rambaut, 2007). We used a Bayesian relaxed molecular clock approach under the uncorrelated lognormal model, and the Yule speciation process was selected, for all data combined. The combined dataset was partitioned by gene. As models implemented in BEAST are not designed to take covariation into account, a separate GTR + G + I substitution was applied to each partition. Model and clock parameters were unlinked across partitions. The topology with optimized branch lengths, previously estimated using PHASE, was specified as a starting tree for the programme BEAST. Duplicate terminals were pruned from the 
tree in TREEEDIT (Rambaut \& Charleston, 2002) so that each species was only represented by a single individual.

Trogidae fossils from the Early Cretaceous serve as useful calibration points for divergence estimates (Krell, 2007; Nikolajev, 2009). We constrained the minimum age of the Omorginae (sensu Nikolajev, 2005) to the late Early Cretaceous (112 Ma) based on the fossil Cretomorgus ikhbogdensis Nikolajev (112.2-121 Ma). The potential minimum age for the Holarctic Trox was constrained to the Mid Cretaceous (98.9 Ma) based on the fossil Trox minutus Nikolajev (98.9-144 Ma). Calibrations were modelled under a lognormal distribution with an offset, mean and standard deviation, so that $95 \%$ of the prior distributions fall within the minimum and maximum ages of the fossils. Parameters of the lognormal distributions were as follows: for T. minutus, offset 98.9, mean 3.075, and standard deviation 0.42 ; for $C$. ikhbogdensis, offset 112.2, mean 1.52 , and standard deviation 0.42 . Two independent MCMC analyses were run for 60 million generations with parameters sampled every 2000 generation, discarding the first 6000 (20\%) trees sampled from each run as burn-in. We kept default settings for all other priors and operators. The application LOGCOMBINER v1.6.2 (Drummond \& Rambaut, 2007) was used to combine the log and tree output files from the two independent runs. TRACER was used to assess the convergence between runs. The module TREEANNOTATOR v1.6.2 (Drummond \& Rambaut, 2007) generated the maximum clade credibility tree and calculated the mean ages (and 95\% confidence intervals).

\section{Results}

The final combined molecular dataset consisted of 107 taxa and $1568 \mathrm{bp}$ (base pairs): $16 \mathrm{~S}=405 \mathrm{bp} ; 18 \mathrm{~S}=562 \mathrm{bp}$ and $28 \mathrm{~S}$ $(\mathrm{D} 2)=601 \mathrm{bp}$. Of the 1568 base pairs, $730(46.6 \%)$ were paired characters, $838(53.4 \%)$ were unpaired and 421 characters were parsimony-informative (refer to Table $\mathrm{S} 4$ for data characteristics and model parameters). The heuristic search from the parsimony analysis produced 49 most parsimonious trees, with tree length $=1779$, consistency index $(\mathrm{CI})=0.381$ and retention index $(\mathrm{RI})=0.840$. The strict consensus tree, with nodal support, is presented in Fig. 2. Neighbour-net analysis of the individual and the concatenated alignment are shown in Fig. 3. The consensus trees for the Bayesian analyses are shown in Fig. 4 and Figures S1 and S2. Summaries of the posterior probabilities (PPs) and bootstrap support (BS) from the neighbour-net, parsimony and Bayesian analyses, for nodes representing subfamilies, genera and subgenera recovered can be seen in Table 2.

\section{Phylogenetic relationships}

Four well-supported monophyletic lineages, Polynoncus (node D), Omorgus (node E), Trox (node H) and Phoberus (node I), were recovered across all methods of analyses (Figs 2, 4). However, tree topologies from the Bayesian analyses using mixed DNA/RNA nucleotide substitution models were overall better resolved (Fig. 4). The latter consistently resolved the deeper phylogenetic relationships within the family, and recovered the two subfamilies, Omorginae (node B) and Troginae (node C) (sensu Nikolajev, 2005). The phylogenetic relationships hypothesized in the following were based on the results of the mixed DNA/RNA model analysis (Fig. 4, Figure S2), and were largely congruent with the existing morphological phylogeny (Fig. 1).

Phylogenetic relationships within Omorginae (node B) were well resolved (Fig. 4). Two monophyletic sister groups deemed equivalent to genera were recovered: Polynoncus (node D) and Omorgus (node E). The genus Omorgus comprised two poorly supported sister clades: Omorgus (node F), representing the New World and Australasian radiations; and Afromorgus (node G), comprising an Afro-Oriental radiation. The only Asian representative of Afromorgus, Afromorgus pauliani (Haaf), included in the study lay in the well-supported (node $\mathrm{O}$ ) clade containing Afromorgus squalidus (Olivier), the type species of the genus.

Within Omorgus there were two distinct lineages: one representing a Neotropical + Nearctic group (node J) containing Omorgus suberosus (Fabricius), the type species of the genus and therefore also of the subgenus Omorgus; and a second, Neotropical + Australian group (node K). This latter clade included three ambiguously resolved clades that were biogeographically coherent but with sparse taxon sampling. One of these clades (node M) contains Omorgus pastillarius (Blanchard), the type species of a formerly recognized subgenus Chesas Burmeister. The Australian species Omorgus gigas Harold is the type species of the former subgenus Megalotrox Preudhomme De Borre and is a relative of Omorgus tatei (Blackburn), found in the well-supported (node N) sister clade containing O. pastillarius (Fig. 1). The third well-supported clade (node L) was also Australian.

Troginae (node C) is composed of two major monophyletic radiations; the Holarctic Trox (node $\mathrm{H}$ ) and the Afrotropical Phoberus (node I). Nearctic, Palaearctic and Oriental Trox species were interspersed on the tree despite obvious geographical separation among species, and although taxon sampling was only 16 species of about 100 in the region, the posterior probabilities were generally reassuring. All of the Afrotropical species were grouped together, contradicting the independent morphological data (Scholtz, 1986a). Taxon sampling of the Afrotropical group was more than adequate; 24 out of 40 known species were included in the analyses and the monophyletic status of Phoberus is not expected to change with increased taxon sampling. The Madagascan species, Trox perrieri Fairmaire, currently placed in the subgenus Trox, was nested on a long branch within the Afrotropical Phoberus lineage.

\section{Neighbour-net graph: general structure and conflict of alignments}

The neighbour-network analysis for the individual and the combined dataset (Fig. 3) revealed the presence of four major clusters (Polynoncus, Omorgus, Trox and Phoberus). These were largely congruent with the topologies recovered from the parsimony and Bayesian analyses (Figs 3,4). Combining the 


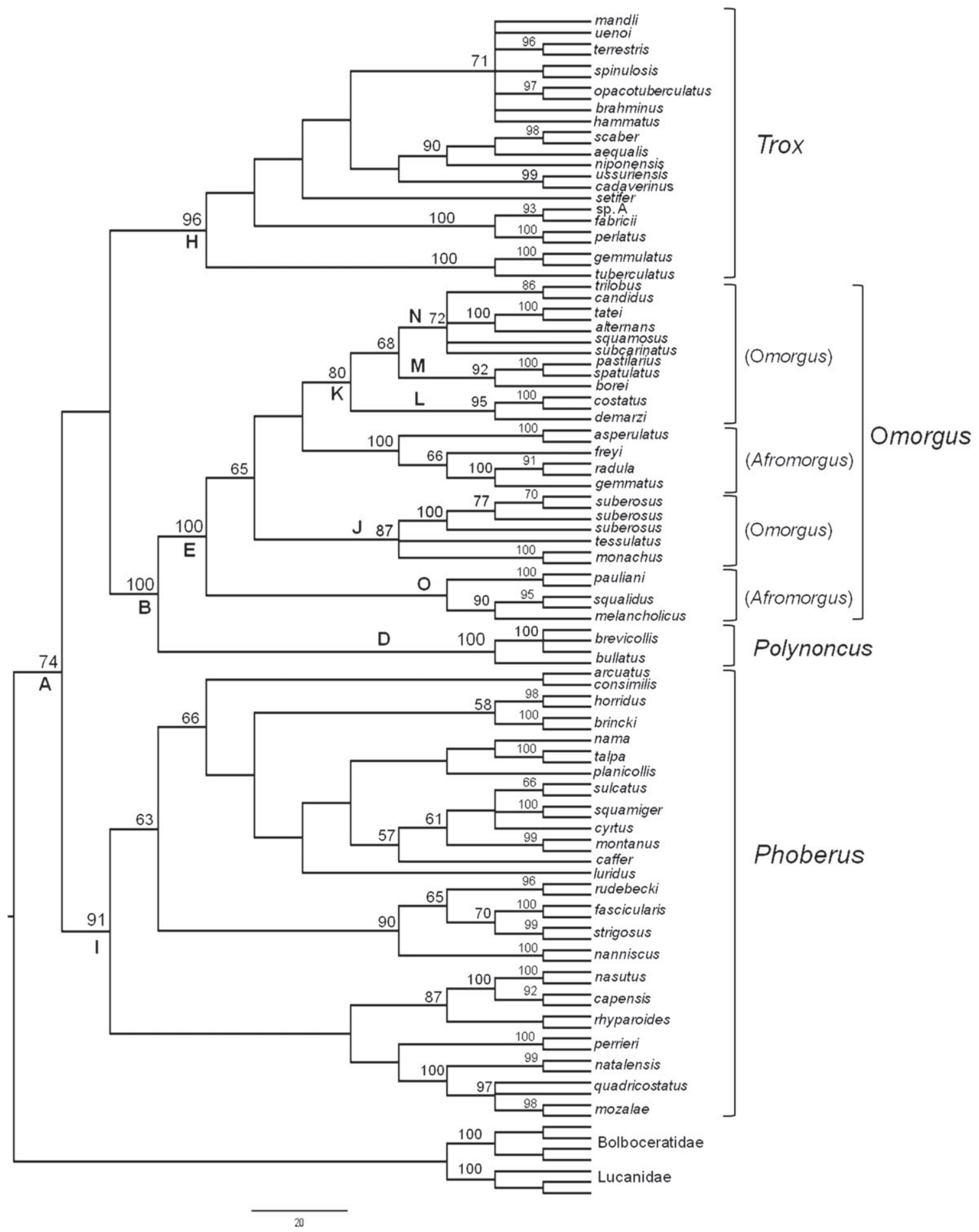

Fig. 2. Strict consensus phylogram for the Trogidae of 49 most parsimonious trees for the combined dataset with bootstrap support. Only bootstrap support $\geq 50$ are shown.

individual datasets in a single analysis improved the split support for a large number of nodes in the splits graph. There was clear split support (long parallel edges) for Polynoncus being the sister group to Omorgus. The generic separation of Afromorgus and
Omorgus was not as well supported by the analysis, and Afromorgus showed evidence of encompassing disparate lineages. The networks showed conflicting splits between Phoberus and Trox, but the Madagascan endemic, T. perrieri, remained closely 
$16 S$

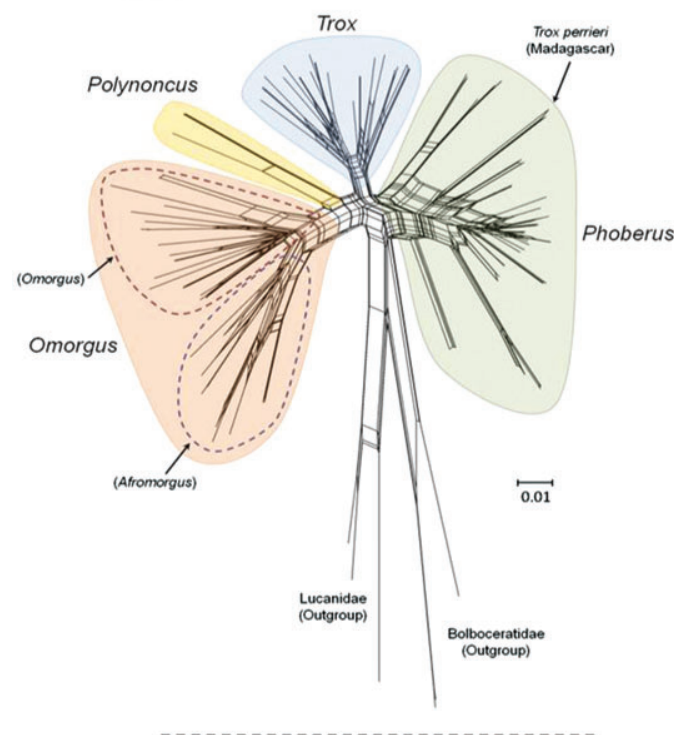

28S D2

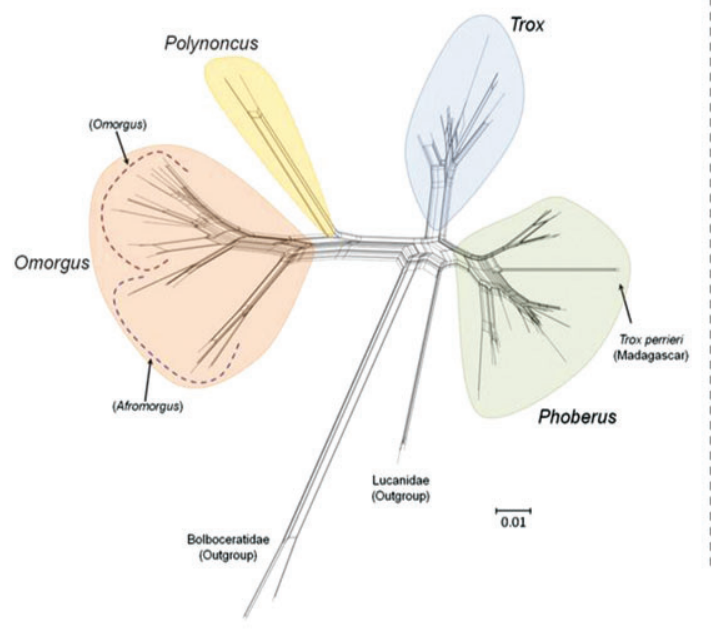

$18 S$

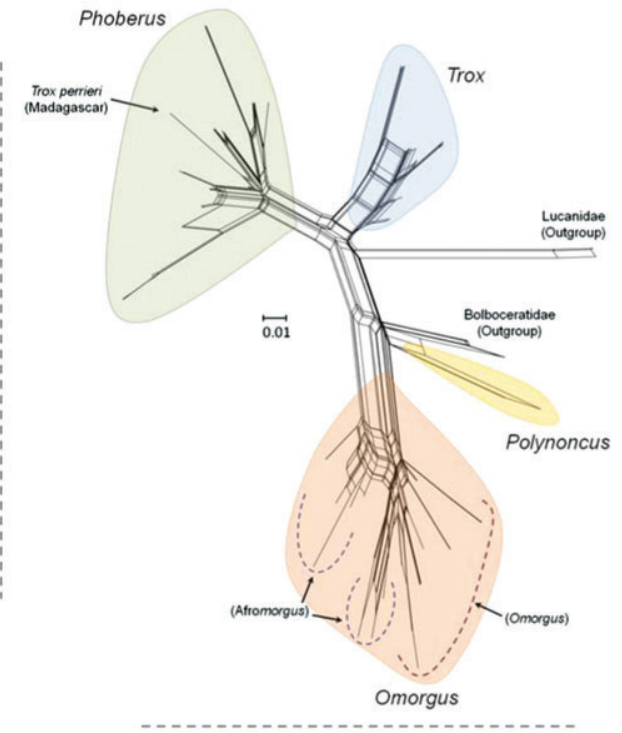

Combined

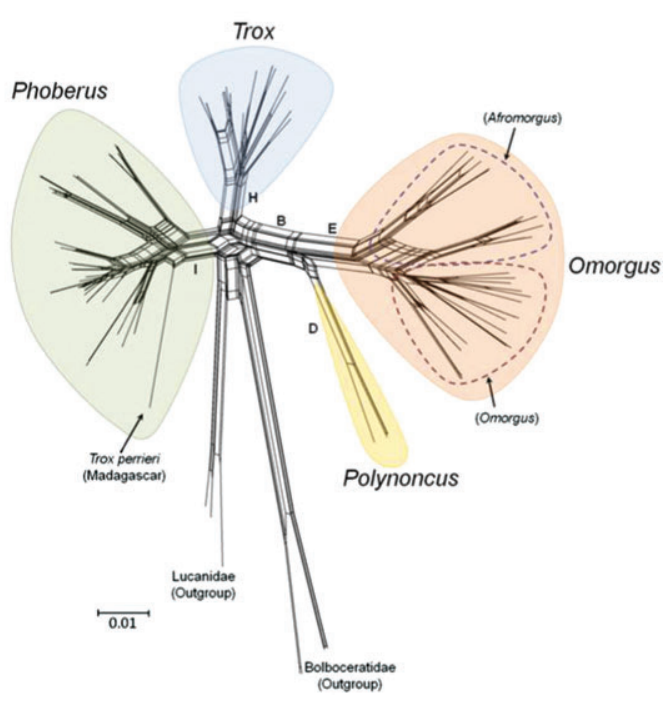

Fig. 3. Neighbour-net graph for the individual and combined molecular datasets, based on uncorrected $p$-distances.

related to the African Phoberus. The support for the major splits is summarized in Table 2.

\section{Divergence time estimates}

BEAST analysis (Fig. 5) dated the origin of Trogidae during the early Jurassic (194 Ma; 95\% confidence interval: 152.7-250.1 Ma). The subfamilies Omorginae (node B) and Troginae (node C) diverged well before the Cretaceous (174 Ma; 139.7-210.4 Ma, well before the Cretaceous node A). The time of divergence between the Holarctic Trox (node $\mathrm{H}$ ) and the Afrotropical Phoberus (node I) was estimated to have occurred during the Late Jurassic (156 Ma; 124.54-189.1 Ma, node C). Omorgus and Polynoncus diverged from their last common ancestor at $117 \mathrm{Ma}(113.63-122.78 \mathrm{Ma})$, also during the mid-Lower Cretaceous (node B). The estimated time of divergence between the subgenera Omorgus (node F) and Afromorgus (node G) was around $90 \mathrm{Ma}(73.82-104.56 \mathrm{Ma}$, node E). The Australian and New World sister groups within Omorgus separated about $81 \mathrm{Ma}(65.53-97.75 \mathrm{Ma}$, node F). The three ambiguously supported lineages subtending the Australian and Neotropical radiations occurred around the Cretaceous/Tertiary boundary (node K). The probable existence of ancestors of the Nearctic Omorgus (node J) at 46 Ma (25.97-67.79 Ma) predates the existing hypothesis of a Pliocene-Pleistocene colonization 


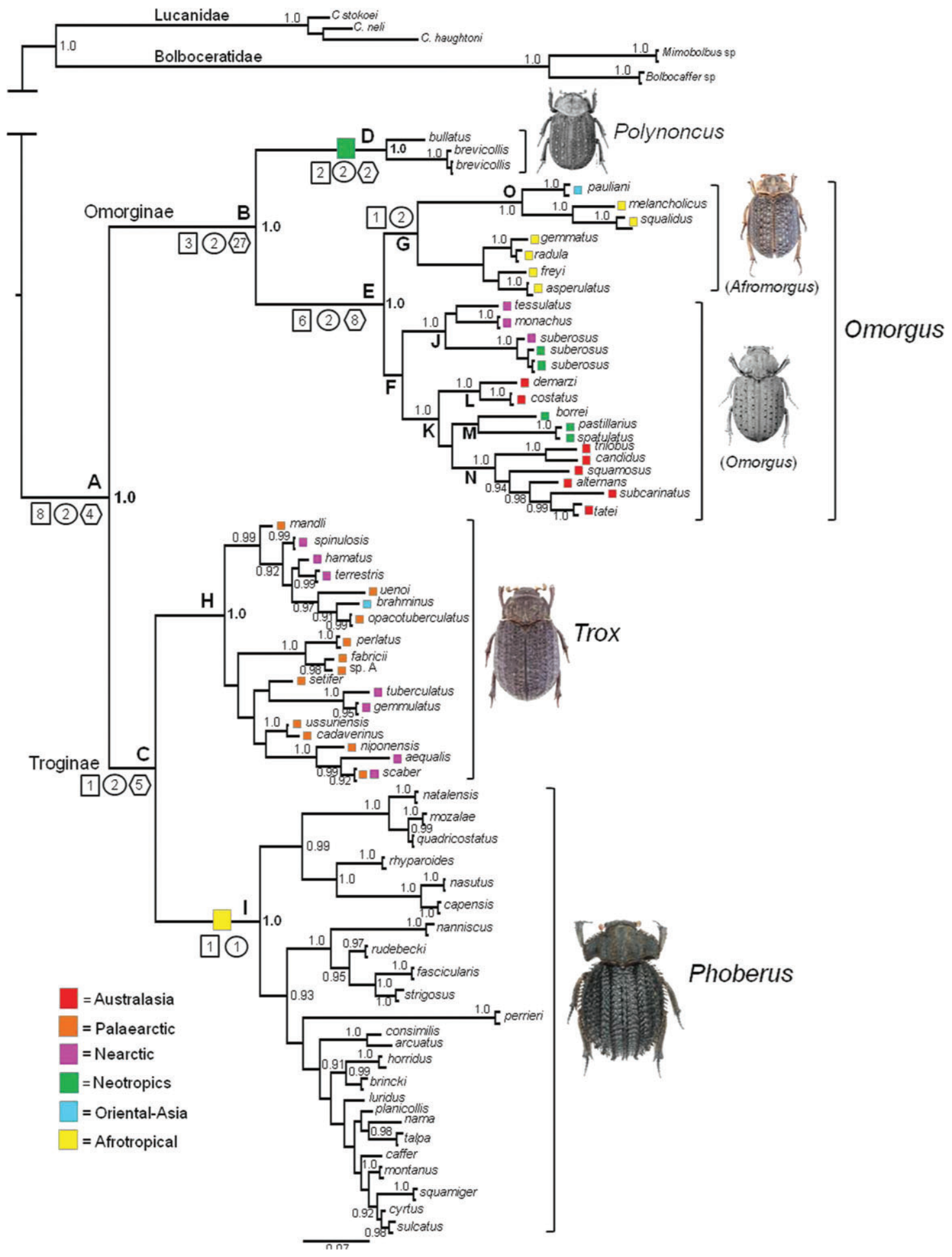

Fig. 4. Bayesian topology from the PHASE analysis. Numbers next to each node are the posterior probability support. Only nodes with posterior probabilities $\geq 90 \%$ are shown. Images depict the type species of the genus or subgenus. Synapomorphic character sets (see Fig. 1) that unite each node are plotted on the phylogram. 
Table 2. Support values for nodes recovered representing subfamilies, genera and subgenera for the parsimony, Bayesian and splits graphs.

\begin{tabular}{lllllll}
\hline & & \multirow{2}{*}{ BI (DNA) } & \multicolumn{2}{c}{ BI (RNA/DNA model) } & MP & NN \\
Node & Taxonomic group & MRBAYES (PP) & MRBAYES (PP) & PHASE (PP) & PAUP (BS) & SPLITSTREE (BS) \\
\hline $\mathrm{A}$ & Trogidae & 0.69 & 1.00 & 1.00 & 74 & - \\
$\mathrm{B}$ & Omorginae (sensu Nikolajev, 2005) & 1.00 & 1.00 & 1.00 & 100 & 97 \\
$\mathrm{C}$ & Troginae (sensu Nikolajev, 2005) & 0.69 & 0.80 & 0.81 & - & - \\
$\mathrm{D}$ & Polynoncus & 1.00 & 1.00 & 1.00 & 100 & 100 \\
$\mathrm{E}$ & Omorgus & 1.00 & 1.00 & 1.00 & 100 & 99 \\
$\mathrm{~F}$ & (Omorgus) & 0.83 & 0.71 & 0.71 & - & - \\
$\mathrm{G}$ & Afromorgus & 0.96 & 0.93 & 0.84 & - & 42 \\
$\mathrm{H}$ & Trox s.s. & 1.00 & 1.00 & 1.00 & 96 & 95 \\
$\mathrm{I}$ & Phoberus & 1.00 & 1.00 & 1.00 & 91 & 94 \\
$\mathrm{~J}$ & Omorgus (Neotropical + Nearctic group) & 1.00 & 1.00 & 1.00 & 87 & 93 \\
$\mathrm{~K}$ & Omorgus (Neotropical + Australian group) & 1.00 & 1.00 & 1.00 & 80 & 51 \\
$\mathrm{~L}$ & Omorgus (Australian group) & 1.00 & 1.00 & 1.00 & 95 & 97 \\
$\mathrm{M}$ & Omorgus (Neotropical group) & 0.98 & 0.90 & 0.89 & 92 & 72 \\
$\mathrm{~N}$ & Omorgus (Australian group) & 1.00 & 1.00 & 1.00 & 72 \\
$\mathrm{O}$ & Afromorgus Asian representative & 1.00 & 1.00 & 1.00 & - & 76 \\
\hline
\end{tabular}

BI, Bayesian inference; MP, maximum parsimony; NN, neighbour-net; PP, posterior probability; BS, bootstrap support.

of North America ( $2 \mathrm{Ma}$ ) from South America for this group (Scholtz, 1986a).

\section{Discussion}

\section{Molecular phylogeny and the systematics of Trogidae}

Our molecular phylogeny supports the morphological phylogeny proposed by Scholtz (1986a) and Scholtz \& Peck (1990) in most aspects, and the subfamily divisions (Trogidae-Omorginae) of Trogidae proposed by Nikolajev (2005). Omorginae was the only subfamily recovered unambiguously. Although there was not particularly strong branch support for the monophyly of Troginae, there are convincing (larval and adult) morphological synapomorphic characters supporting the monophyly of Troginae and similarly for Omorginae (Scholtz, 1986a; Scholtz \& Peck, 1990; Browne et al., 1993; Nikolajev, 2005; Figs 1, 4).

Within Omorginae, the genera Omorgus and Polynoncus are recovered as monophyletic and the sister group relationship is clearly supported by both morphological and molecular data (Figs 1, 4). The genus Omorgus is divided into two groups: (i) Omorgus, representing the Australasian and New World species; and (ii) Afromorgus, containing all the Afrotropical and Asian species. Afromorgus is morphologically easily separated from Omorgus on the basis of two apomorphic characters on the male genitalia: (i) pars basalis fused dorsally; and (ii) median lobe complex, not simple (Scholtz, 1986a). Pittino (2006) considered the aforementioned characters important enough to elevate Afromorgus to generic status. However, our results clearly indicate that Afromorgus is a well-defined subgroup within the genus Omorgus and the generic separation of Afromorgus and Omorgus s.s. is not supported. We intuitively follow the classification system for the genus Omorgus and its subgenera, as proposed by Scholtz (1986a).
The subgenus Omorgus may well comprise several lineages equivalent to subgenera, but evidence for their monophyly is equivocal. Our results tentatively suggest resurrection of two former subgeneric names, Megalotrox and Chesas. The former is assignable to all Australian Omorgus species and the latter to some Neotropical representatives. Scholtz (1986a) was unable to provide any support for these species representing a monophyletic group in the morphological phylogenetic reconstruction of the family and synonymized it with Omorgus. Burmeister (1876) considered $O$. pastillarius unique among the Argentine species, on account of it being flightless, and placed it in the Chesas group which was later treated as a subgenus by Preudhomme de Borre (1886). Chesas was subsequently synonymized with Omorgus (Vaurie, 1962; Baker, 1968; Scholtz, 1986b). At present, we prefer not to recognize these groups formally without unequivocal evidence.

The subfamily Troginae consists of two monophyletic groups, the Holarctic Trox and the Afrotropical Phoberus. Trox are found in most of the major biomes of the Holarctic (Scholtz, 1982, 1986b; Pittino, 2006; Scholtz et al., 2007). However, Palaearctic, Nearctic and Oriental groups show little phylogenetic separation, indicating probable repeated lineage-mixing across Beringia in various pulses, in response to glacial and interglacial episodes.

All the Afrotropical species group naturally together in Phoberus, contrary to morphological evidence that the subgenus may be polyphyletic (Scholtz, 1986a). The close relationship of the Madagascan T. perrieri to the African Phoberus points unequivocally to dispersal from Africa, across the Mozambique Channel, to Madagascar (Nazari et al., 2011; Sole et al., 2011; Samonds et al., 2012). Haaf (1953) considered T. perrieri related to other members on the mainland, which is supported by molecular evidence.

MacLeay (1819), in addition to proposing the family name, described the genus Phoberus to accommodate the large flightless southern African species, Trox horridus Fabricius. However, 


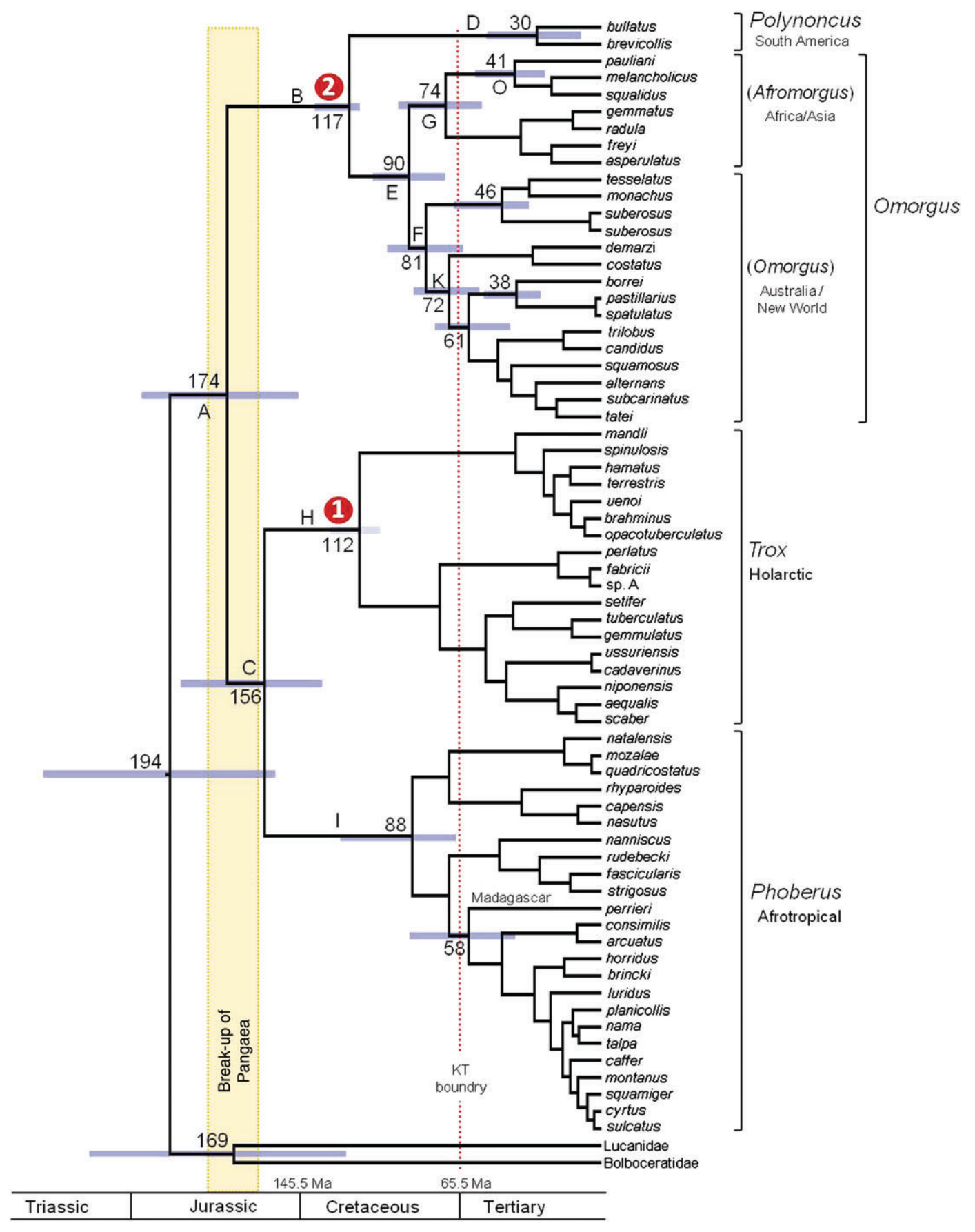

Fig. 5. Maximum clade credibility chronogram for Trogidae from the BEAST analysis. Age estimates for the major divergence events (in millions of years) with 95\% highest posterior density intervals are depicted by node bars. Node labels 1 and 2 indicate fossil constraints.

Phoberus was not generally recognized as a genus; Burmeister (1876) and Preudhomme De Borre (1886) considered Phoberus to represent a subgenus, including only the type species. Harold (1872) and Scholtz (1979) considered Phoberus a synonym of the genus Trox, whereas Haaf (1953) treated Phoberus only as a species group. Péringuey (1900), Arrow (1912) and, later, Scholtz $(1980,1982)$ treated Phoberus as a subgenus of Trox, but they differed in their views regarding inclusion of taxa in the subgenus. The results of the molecular phylogeny justify reinstating the genus Phoberus MacLeay to accommodate all Afrotropical (sub-Saharan) species.

The contemporary classification of this family has been based exclusively on morphological characters. Our molecular phylogeny, the first for the family, provides strong support 
for the relationships between morphologically described genera and subgenera. On the basis of this study, it is now proposed that certain taxonomic changes to the generic classification of the family be made. The phylogenetic classification proposed closely follows the classification of Scholtz (1986a), except that we support Nikolajev's division of Trogidae into two subfamilies, Omorginae and Troginae, and suggest that the subgenera Trox and Phoberus be elevated to genera, with Afromorgus being returned to subgeneric rank. The Madagascan species, T. (Trox) perrieri, is transferred to Phoberus. The taxonomic changes we propose here will be formalized in a separate publication.

\section{Historical biogeography}

The divergence dating analysis proposed a Jurassic origin for extant Trogidae. Although it is difficult to identify the exact area of origin of Trogidae, we consider modern north-east Asia as an important candidate centre for their evolution. Mesozoic fossils assignable to Troginae and Omorginae (Krell, 2007; Nikolajev, 2009) and various basal Scarabaeoidea (Nikolajev, 2008a-d, 2010; Bai et al., 2010, 2012, 2013; Nikolajev \& Ren, 2010) support this view.

The north-south split of Pangaea (180-160 Ma) is considered a key geological event in the diversification of the extant Trogidae (Scholtz, 1986a). The divergence between the two subfamilies Omorginae and Troginae coincides with the initial fragmentation of the supercontinent during the Middle Jurassic, whereas the divergence of Holarctic Trox and African Phoberus corresponds to the final opening of the Tethyan seaway that eventually separated the two landmasses in the Late Jurassic (Stanley, 1986).

The evolution of Omorgus and Polynoncus proposed by Scholtz (1986a) remains plausible according to our results. Ancestral Omorginae radiated extensively on West Gondwana following the fragmentation of the supercontinent. Scholtz (1986a) hypothesized that the ancestor of Omorgus + Afromorgus diverged vicariantly when Africa and South America separated. This implies that the two lineages would have diverged in the Late Cretaceous. Our estimate for divergence between the two subgenera ( $~ 90 \mathrm{Ma})$, although it post-dated the presumed vicariant event (at about $100 \mathrm{Ma}$ ), is compatible with early Late Cretaceous separation of Africa from South America (Sereno et al., 2004; Van Bocxlaer et al., 2006). The alternative scenario is that speciation occurred more recently following long-distance dispersal from South America to Africa. The credibility interval $(73.82-104.56 \mathrm{Ma})$ is wide enough to allow for both scenarios. Although long-distance dispersal is possible (e.g. Price et al., 2011), the morphological differences between Afromorgus and Omorgus are substantial, reflecting a long period of isolation between the two groups. We tentatively conclude that Afromorgus and Omorgus diverged vicariantly when Africa and South America finally separated during the Late Cretaceous. The radiation of Afromorgus, estimated at 74 (90-54) Ma, occurred after the separation of Africa from South America, considering that the subgenus is absent from the New World and Australasian Region. Afromorgus occurs throughout the Afrotropics and extends into Arabia, the Oriental and Indo-Malayan regions (Scholtz, 1980, 1986a).

The biogeography of the New World and Australasian Omorgus is complex and appears to be the result of post-Gondwana dispersal. The dispersal of ancestral Omorgus from South America into North America probably occurred during the Late Cretaceous to the Early Eocene when the two continents were connected across the proto-Caribbean archipelago, which formed when South America rifted from Africa (Sanmartín \& Ronquist, 2004). There is evidence that the archipelago served as an important biotic exchange route (i.e. the first invasion of marsupial and placental mammals) since the mid-Cretaceous (Feller \& Hedges, 1998; Sanmartín \& Ronquist, 2004; Ortiz-Jaureguizar \& Pascual, 2011).

A post-Gondwanan Antarctic connection between southern landmasses probably facilitated dispersal of South American Omorgus into Australia (Trewick, 2000; Almeida et al., 2012). Divergence estimates are congruent with the time period when Australia, Antarctica and South America remained connected. The trans-Antarctic corridor served as an important dispersal route for the exchange of southern temperate biota between South America and Australia, since the Late Cretaceous and until the Early Palaeogene (Lawver et al., 1992; Woodburne \& Case, 1996; Sanmartín \& Ronquist, 2004; Almeida et al., 2012; see also Ali \& Aitchison, 2009). Biotic exchange between southern landmasses was eventually disrupted by global cooling and the physical separation of the continents (Upchurch, 2008; Almeida et al., 2012).

Polynoncus forms a well-defined group that evolved from an Omorgus-like ancestor in South America. The group is endemic to the continent, and radiation into the temperate regions probably occurred only after continental fragmentation. The formation of the Andes mountain range probably provided the temperate biome preferred by members of this genus, the majority of which are restricted to the southern one-third of the continent (Patagonian sub-region) (Scholtz, 1990).

Our results suggest a different evolution for the Trox and Phoberus from that proposed by Scholtz (1986a). Troginae may have diverged vicariantly when the opening of the Tethyan seaway finally separated Laurasia and Gondwana. The lineage confined to Africa gave rise to Phoberus, and the Laurasian lineage to Trox. According to the fossil evidence, modern East Asia was most likely the ancestral area of origin for extant Trox, which lends support to the proposed Laurasian origin for this genus (Scholtz, 1986a; Krell, 2007; Nikolajev, 2008a, 2009). Phoberus is endemic to continental Africa, which is probably a direct result of the geographic isolation of the African continent from the Middle Cretaceous to the Early Miocene following the fragmentation of Gondwana (Gheerbrant \& Rage, 2006). The presence of Phoberus in Madagascar is best explained by sweepstakes dispersal (Rabinowitz \& Woods, 2006; Ali \& Huber, 2010). Out-of-Africa dispersal to the island during the Palaeogene ( 60 to $20 \mathrm{Ma}$ ) period was largely facilitated by ocean currents that flowed from the mainland towards Madagascar (Rabinowitz \& Woods, 2006; Ali \& Huber, 2010, Samonds et al., 2012). Trans-oceanic dispersal from Africa to Madagascar 
has been successfully invoked for various groups of mammals, amphibians, reptiles, insects (including dung beetles) and plants (Yoder \& Nowak, 2006; Sole et al., 2011; Townsend et al., 2011; Zhou et al., 2012).

\section{Conclusion}

In this study, we have provided the first molecular phylogeny for this group and successfully resolved relationships between and within genera and subgenera for the family. One of the more surprising results was the monophyly of Phoberus. Based on the evidence, we propose reinstating the genus Phoberus to accommodate all Afrotropical (including Madagascan endemic) species. The results re-emphasize the validity of the classification system for the genus Omorgus and its subgenera, as proposed by Scholtz (1986a). The study provides evidence of the Madagascan trogid fauna having an African origin. Colonization of the island probably occurred via dispersal from the mainland as opposed to ancient vicariant events. Divergence analysis was able to date the major events for the origin of extant lineages of Trogidae. The subsequent diversification of the major lineages is largely attributed to Pangaea and Gondwana vicariance events in the Mid-Jurassic and early Late Cretaceous, respectively. The separation of the landmasses resulted in the evolution of four distinct groups: Omorgus, Polynoncus, Trox and Phoberus. Phylogenetic sub-division within the family indicates a complex evolutionary history for the four major groups, and further studies should investigate the regional biogeography of the major lineages. Trogidae constitute a monophyletic and biologically unique family within Scarabaeoidea. It is clear that the switch to keratin feeding very early in scarabaeoid evolution provided trogids with a readily available food source that is mostly free of competitors, and this has remained the case since their initial radiation. To this day they are among the very last of the succession of insects that colonize and feed on animal remains, an adaptation that has endured and stood them in good stead since the Jurassic.

\section{Supporting Information}

Additional Supporting Information may be found in the online version of this article under the DOI reference:

10.1111/syen.12074

Figure S1. Phylogeny of Trogidae inferred from the combined 16S, 28S domain 2 and 18S (sequence-based aligned) dataset and implementing a conventional DNA model setup using MrBayes.

Figure S2. Phylogeny of Trogidae inferred from the combined 16S, 28S domain 2 and 18S (sequence-based aligned) dataset and implementing a mixed RNA/DNA (16-state RNA) model setup using MRBAYES.

Table S1. List of taxa used in this study along with their GenBank accession numbers and locality data. X, indicates that PCR amplification failed.
Table S2. Summary of oligonucleotide primers used in this study.

Table S3. PCR thermal cycling profiles.

Table S4. Data characteristics and estimated model parameters for $16 \mathrm{~S}, 28 \mathrm{~S}$ domain $2,18 \mathrm{~S}$ and combined dataset.

\section{Acknowledgements}

The authors are extremely grateful to the following people (listed alphabetically), who have kindly provided specimens for our study: Olivier Boilly, Christian Deschodt, Federico Ocampo, Vasily Grebennikov, James Harrison, Terry F. Houston, Paul Hutchinson, Li Jingke, Paul K. Lago, Darren Mann, Claudia Medina, Geoff Monteith, Wendy Moore, Philippe Moretto, Sergey Tarasov and Shaun Whipple. Many thanks to Sergey Tarasov for his help in translating Russian literature. We also thank two anonymous reviewers and the editor for constructive comments on the manuscript.

\section{References}

Ali, J.R. \& Aitchison, J.C. (2009) Kerguelen Plateau and the late Cretaceous southern-continent bioconnection hypothesis: tales from a topographical ocean. Journal of Biogeography, 36, 1778-1784.

Ali, J.R. \& Huber, M. (2010) Mammalian biodiversity on Madagascar controlled by ocean currents. Nature, 463, 653-656.

Almeida, E.A.B., Pie, M.R., Brady, S.G. \& Danforth, B.N. (2012) Biogeography and diversification of colletid bees (Hymenoptera: Colletidae): emerging patterns from the southern end of the world. Journal of Biogeography, 39, 526-544.

Arrow, G.J. (1912) Scarabaeidae, Troginae, Coleopterorum Catalogus, Pars 43 (ed. by W. Junk and S. Schenkeling), pp. 52-66. W. Junk, Berlin.

Bai, M., Krell, F.-T., Ren, D. \& Yang, X.-K. (2010) A new, well preserved species of Glaresidae (Coleoptera: Scarabaeoidea) from the Jehol Biota of China. ACTA Geologica Sinica, 84, 676-679 (English edition).

Bai, M., Ahrens, D., Yang, X.-K. \& Ren, D. (2012) New fossil evidence of the early diversification of scarabs: Alloioscarabaeus cheni (Coleoptera: Scarabaeoidea) from the Middle Jurassic of Inner Mongolia, China. Insect Science, 19, 159-171.

Bai, M., Beutel, R.G., Shih, C., Ren, D. \& Yang, X.-K. (2013) Septiventeridae, a new and ancestral fossil family of Scarabaeoidea (Insecta: Coleoptera) from the Late Jurassic to Early Cretaceous Yixian Formation. Journal of Systematic Palaeontology, 11, 359-374.

Baker, C.W. (1968) Larval taxonomy of the Troginae in North America with notes on biologies and life histories (Coleoptera: Scarabaeoidea). Bulletin of the U.S. National Museum, 279, 1-79.

Balthasar, V. (1936) Monographie der Subfamilie Troginae der palaearktischen Region. Festschrift zum 60. Geburtstage von Prof. Dr. Embrik Strand, Vol. 1, pp. 407-459. Izdevniecība, Riga, Latvia.

Browne, D.J. \& Scholtz, C.H. (1995) Phylogeny of the families of Scarabaeoidea (Coleoptera) based on characters of the hindwing articulation, hindwing base and wing venation. Systematic Entomology, 20, 145-173.

Browne, J. \& Scholtz, C.H. (1999) A phylogeny of the families of Scarabaeoidea (Coleoptera). Systematic Entomology, 24, 51-84. 
Browne, D.J., Scholtz, C.H. \& Kukalová-Peck, J. (1993) Phylogenetic significance of wing characters in the Trogidae (Coleoptera: Scarabaeoidea). African Entomology, 1, 195-206.

Burmeister, H.C.C. (1876) Die argentinischen Arten der Gattung Trox F. Stettiner Entomologische Zeitung, 37, 241-268.

D'Hotmann, D. \& Scholtz, C.H. (1990) Phylogenetic significance of the structure of the external male genitalia in the Scarabaeoidea (Coleoptera). Entomology Memoirs, 77, 19-22.

Drummond, A.J. \& Rambaut, A. (2007) BEAST: bayesian evolutionary analysis by sampling trees. BMC Evolutionary Biology, 7, 214.

Elven, H., Bachmann, L. \& Gusarov, V.I. (2010) Phylogeny of the tribe Athetini (Coleoptera: Staphylinidae) inferred from mitochondrial and nuclear sequence data. Molecular Phylogenetics and Evolution, 57, $84-100$.

Feller, A.E. \& Hedges, S.B. (1998) Molecular evidence for the early history of living amphibians. Molecular Phylogenetics and Evolution, 9, 509-516.

Felsenstein, J. (1985) Confidence limits on phylogenies: an approach using the bootstrap. Evolution, 39, 783-791.

Gazave, E., Lapébie, P., Renard, E., Vacelet, J., Rocher, C., Ereskovsky, A.V., Lavrov, D.V. \& Borchiellini, C. (2010) Molecular phylogeny restores the supra-generic subdivision of Homoscleromorph sponges (Porifera, Homoscleromorpha). PLoS One, 5, e14290. DOI: 10.1371/journal.pone.0014290.

Gheerbrant, E. \& Rage, J. (2006) Paleobiogeography of Africa: how distinct from Gondwana and Laurasia. Palaeogeography, Palaeoclimatology, Palaeoecology, 241, 224-246.

Gillespie, J.J., Johnston, J.S., Cannone, J.J. \& Gutell, R.R. (2006) Characteristics of the nuclear (18S, 58S, $28 \mathrm{~S}$ and $5 \mathrm{~S}$ ) and mitochondrial (12S and 16S) rRNA genes of Apis mellifera (Insecta: Hymenoptera): structure, organization, and retrotransposable elements. Insect Molecular Biology, 15, 657-686.

Gowri-Shankar, V. \& Jow, H. (2006) PHASE: A Software Package for Phylogenetics and Sequence Evolution V2.0. University of Manchester, Manchester.

Grebennikov, V.V. \& Scholtz, C.H. (2004) The basal phylogeny of Scarabaeoidea (Insecta: Coleoptera) inferred from larval morphology. Invertebrate Systematics, 18, 321-348.

Gruber, A.R., Lorenz, R., Bernhart, S.H., Nueböck, R. \& Hofacker, I.L. (2008) The Vienna RNA websuite. Nucleic Acids Research, 36, W70-W74

Haaf, E. (1953) Die afrikanischen und orientalischen Arten der Gattung Trox F. (Col. Scarab.). 1. Beitrag zur Kenntnis der Subfam. Troginae. Entomologische Arbeiten aus dem Museum George Frey, 4, 309-346.

Haaf, E. (1954a) Die afrikanischen und orientalischen Arten der Gattung Trox F. (Col. Scarab.). 2. Beitrag zur Kenntnis der Subfam. Troginae. Entomologische Arbeiten aus dem Museum George Frey, 4, 326-396.

Haaf, E. (1954b) Die australischen Arten der Gattung Trox F. (Col. Scarab.). Entomologische Arbeiten aus dem Museum George Frey, 5, 691-740.

Harold, E. (1872) Monographie der Gattung Trox. Coleopterologische Hefte, 9, 1-192.

Hofacker, I.L. (2003) Vienna RNA secondary structure server. Nucleic Acids Research, 31, 3429-3431.

Hunt, T., Bergsten, J., Lekanikova, Z. et al. (2007) A comprehensive phylogeny of beetles reveals the evolutionary origins of a super radiation. Science, 318, 1913-1916.

Huson, D.H. \& Bryant, D. (2006) Application of phylogenetic networks in evolutionary studies. Molecular Biology and Evolution, 23, $254-267$.

Jow, H., Hudelot, C., Rattray, M. \& Higgs, P. (2002) Bayesian phylogenetics using an RNA substitution model applied to early mammalian evolution. Molecular Biology and Evolution, 19, 1591-1601.
Katoh, K. \& Toh, H. (2008) Recent developments in the MAFFT multiple sequence alignment program. Briefings in Bioinformatics, $\mathbf{9}$, 286-298.

Krell, F.T. (2007) Catalogue of Fossil Scarabaeoidea (Coleoptera: Polyphaga) of the Mesozoic and Tertiary, Version 2007. Denver Museum of Nature and Science Technical Report No. 2007-2008. Denver Museum of Nature and Science, Denver, Colorado.

Kück, P. \& Meusemann, K. (2010a) FASconCAT: convenient handling of data matrices. Molecular Phylogenetics and Evolution, 56, $1115-1118$.

Kück, P. \& Meusemann, K. (2010b) FASconCAT, Version 1.0, Zool. Forschungsmuseum A. Koenig, Bonn. [WWW document]. URL http://software.zfmk.de [accessed on 6 October 2011].

Lawrence, J.F., Slipinski, A., Seago, A.E., Thayer, M.K., Newton, A.F. \& Marvaldi, A.E. (2011) Phylogeny of the Coleoptera based on morphological characters of adults and larvae. Annales Zoologici, 61 , $1-217$.

Lawver, L.A., Gahagan, L.M. \& Coffin, M.F. (1992) The development of paleoseawaysaround Antarctica. The Antarctic Paleoenvironment: A Perspective on Global Change, Antarctic Research Series, Vol. 56 (ed. by J.P. Kennet and D.A. Warnke), pp. 7-30. American Geophysical Union, Washington, District of Columbia.

MacLeay, W.S. (1819) Horae Entomologiae, or Essay on the Annulose Animals, Vol. 1. Bagster, London.

McKenna, D.D. \& Farrell, B. (2009) Beetles (Coleoptera). The Timetree of Life (ed. by S.B. Hedges and S. Kumar), pp. 278-789. Oxford University Press, New York, New York.

Nazari, V., Larsen, T.B., Lees, D.C., Brattström, O., Bouyer, T., Van de Poel, G. \& Herbert, P.D.N. (2011) Phylogenetic systematics of Colotis and associated genera (Lepidoptera: Pieridae): evolutionary and taxonomic implications. Journal of Zoological Systematics and Evolutionary Research, 49, 204-215.

Nel, A. \& Scholtz, C.H. (1990) Comparative morphology of the mouthparts of adult Scarabaeoidea (Coleoptera). Entomology Memoir, 80, $28-29$.

Nikolajev, G.V. (2005) Omorgini (Coleoptera, Scarabaeidae, Troginae) - a new tribe of scarab beetles. Euroasian Entomological Journal, 4, 321-322 (in Russian).

Nikolajev, G.V. (2007) Mezozoiskii etap evolyutsii plastinchatousykh (Insecta: Coleoptera: Scarabaeoidea). Kazak Universiteti, Almaty.

Nikolajev, G.V. (2008a) A new species of the genus Trox F. (Coleoptera: Scarabaeoidea: Trogidae) from the Lower Cretaceous of Siberia. Bulletin of the National Academy of Science of the Republic of Kazakhstan, 4, 55-56.

Nikolajev, G.V. (2008b) The family Geotrupidae (Coleoptera) from the Lower Cretaceous of Asia. Tethys Entomological Research, 16, $31-36$.

Nikolajev, G.V. (2008c) A new species of the genus Jurahybosorus Nikolajev (Coleoptera, Scarabaeoidea: Hybosoridae) from the Upper Jurassic of Kazakhstan. Tethys Entomological Research, 16, 27-30.

Nikolajev, G.V. (2008d) A new species of the subfamily Aphodiinae (Coleoptera: Scarabaeidae) from the Lower Cretaceous of Transbaikalia. Caucasian Entomological Bulletin, 4, 291-293.

Nikolajev, G.V. (2009) A new genus and species of the family Trogidae (Coleoptera: Scarabaeoidea) from the Lower Cretaceous of Mongolia. Caucasian Entomological Bulletin, 5, 179-182.

Nikolajev, G.V. (2010) A new genus of the subfamily Anaidinae (Coleoptera, Scarabaeoidea, Hybosoridae) from the Mesozoic of Transbaikalia. Paleontological Journal, 44, 192-194.

Nikolajev, G.V. \& Ren, D. (2010) The oldest fossil Ochodaeidae (Coleoptera: Scarabaeoidea) from the Middle Jurassic of China. Zootaxa, 2553, 65-68.

Nylander, J.A.A., Wilgenbusch, J.C., Warren, D.L. \& Swafford, D.L. (2008) AWTY (are we there yet?): a system for graphical exploration 
of MCMC convergence in Bayesian phylogenetics. Bioinformatics, 24, 581-583.

Ortiz-Jaureguizar, E. \& Pascual, R. (2011) The tectonic setting of the Caribbean region and the K/T turnover of the South American land-mammal fauna. Boletin Geológico y Minero, 122, 333-344.

Péringuey, L. (1900) Descriptive catalogue of the Coleoptera of South Africa (Lucanidae and Scarabaeidae). Transactions of the South African Philosophical Society, 12, 1-920.

Pittino, R. (1983) Trox (s. str.) granulipennis Fairm. and allied taxa, with two new species from Mediterranean area (Coleoptera: Trogidae) (XXV contribution to the knowledge of Coleoptera Scarabaeoidea). Giornale Italiano di Entomologia, 1, 265-284.

Pittino, R. (1985) Four new Oriental species of the genus Trox (s.str.) F. (Coleoptera: Trogidae) (XXIX contribution to the knowledge of Coleoptera Scarabaeoidea). Giornale Italiano di Entomologia, 2, 327-340.

Pittino, R. (2006) Trogidae. Catalogue of Palaearctic Coleoptera, Scarabaeoidea, Scirtoidea, Dascilloidea, Buprestoidea, Byrrhoidea, Vol. 3 (ed. by I. Löbl and A. Smetana), pp. 26-28; 79-81, 690 pp. Apollo Books, Stenstrup.

Pittino, R. (2010) A new genus and species of Trogidae MacLeay, 1819 from Madagascar, and a new species of Omorgus Erichson, 1847 from Argentina (Coleoptera, Trogidae). Kogane, 11, 75-83.

Posada, D. (2008) jModelTest: phylogenetic model averaging. Molecular Biology and Evolution, 25, 1253-1256.

Preudhomme de Borre, F.P.C.A. (1886) Catalogue des Trogides décrits jusqu'à le jour precede d'un synopsis de leurs genres et d'une esquisse de leur distribution géographique. Annales de la Société Entomologique de Belgique, 30, 54-68.

Price, B.W., Villet, M.H., Walton, S.M. \& Barker, N.P. (2011) Using molecules and morphology to infer the phylogenetic relationships and evolutionary history of the Dirini (Nymphalidae: Satyrinae), a tribe of butterflies endemic to Southern Africa. Systematic Entomology, 36, $300-316$.

Rabinowitz, P.D. \& Woods, S. (2006) The Africa-Madagascar connection and mammalian migrations. Journal of African Earth Sciences, 44, 270-276.

Rambaut, A. (2009) Figtree v1.3.1 [WWW document]. URL http://tree. bio.ed/ac.uk/software/figtree/ [accessed on 21 December 2009].

Rambaut, A. \& Charleston, M. (2002) Phylogenetic Tree Editor and Manipulator v1.0 Alpha. Department of Zoology, University of Oxford, Oxford. [WWW document]. URL http://tree. bio.ed.ac.uk/software/treeeddit [accessed on 31 October 2011].

Rambaut, A. \& Drummond, A.J. (2007) Traces v1.5 [WWW document]. URL http://www.beast.bio.ed.ac.uk/tracer [accessed on 11 February 2013].

Ronquist, F. \& Huelsenbeck, J.P. (2003) MRBAYES 3: bayesian phylogenetic inference under mixed models. Bioinformatics, 19, $1572-1574$.

Samonds, K.E., Godfrey, L.R., Ali, J.R., Goodman, S.M., Vences, M., Sutherland, M.R., Irwin, M.T. \& Krause, D.W. (2012) Spatial and temporal arrival patterns of Madagascar's vertebrate fauna explained by distance, ocean currents, and ancestor type. Proceedings of the National Academy of Sciences of the United States of America, 109, 5352-5357. DOI: 10.1073/pnas.1113993109.

Sanmartín, I. \& Ronquist, F. (2004) Southern Hemisphere biogeography inferred by event-based models: plants versus animal patterns. Systematic Biology, 53, 216-243.

Savill, N.J., Hoyle, D.C. \& Higgs, P.G. (2001) RNA sequence evolution with secondary structure constraints: comparison of substitution rate models using maximum likelihood methods. Genetics, 157, 399-411.

Scholtz, C.H. (1979) The 'horridus'-group of Trox F. species (Coleoptera: Trogidae) in South Africa. Journal of the Entomological Society of southern Africa, 42, 169-180.
Scholtz, C.H. (1980) Monograph of the genus Trox F (Coleoptera: Trogidae) of subsaharan Africa. Cimbebasia Memoir, 4, 1-104.

Scholtz, C.H. (1982) Catalogue of world Trogidae (Coleoptera: Scarabaeoidea). Entomology Memoir, Department of Agriculture and Fisheries, Republic of South Africa, 54, 1-27.

Scholtz, C.H. (1986a) Phylogeny and systematics of the Trogidae (Coleoptera: Scarabaeoidea). Systematic Entomology, 11, 355-363.

Scholtz, C.H. (1986b) Revision of the genus Trox Fabricius (Coleoptera: Trogidae) of the Australasian Region. Australian Journal of Zoology: Supplementary Series, 125, 1-99.

Scholtz, C.H. (1990) Revision of the Trogidae of South America (Coleoptera: Scarabaeoidea). Journal of Natural History, 24, $1391-1456$.

Scholtz, C.H. (1991) Descriptions of larvae of Australian Omorgus Erichson, with implications for the phylogeny of the Trogidae (Insecta: Coleoptera). Invertebrate Taxonomy, 5, 827-835.

Scholtz, C.H. (1993) Descriptions of larvae of African Trogidae (Coleoptera), with implications for the phylogeny of the family. African Entomology, 1, 1-13.

Scholtz, C.H. \& Chown, S.L. (1995) The evolution of habitat use and diet in the Scarabaeoidea: phylogenetic approach. Biology, Phylogeny and Classification of Coleoptera: Papers Celebrating the 80th Birthday of Roy A. Crowson, pp. 355-374. Muzeum I Instytut Zoologii PAN, Warsaw.

Scholtz, C.H. \& Peck, S. (1990) Description of a Polynoncus Burmeister larva, with implications for phylogeny of the Trogidae (Coleoptera: Scarabaeoidea). Systematic Entomology, 15, 383-389.

Scholtz, C.H., Inward, D.J.G. \& Kerley, M.D. (2007) Description of a new Palaearctic Trox Fabricius species (Coleoptera: Trogidae) from Thailand, with a review of the Trox opacotuberculatus species-group and its biogeography. Insect Systematics and Evolution, 38, 93-103.

Schöniger, M. \& von Haeseler, A. (1994) A stochastic model for the evolution of autocorrelated DNA sequences. Molecular Phylogenetics and Evolution, 3, 240-247.

Sereno, P.C., Wilson, J.A. \& Conrad, J.L. (2004) New dinosaurs link southern landmasses in the mid-Cretaceous. Proceedings of the Royal Society of London B: Biological Sciences, 271, 1325-1330.

Smith, A.B.T. (2003) Checklist of the Scarabaeoidea of the Nearctic Realm. Version 3. Electronically Published, Lincoln, Nebraska.

Smith, A.B.T., Hawks, D.C. \& Heraty, J.M. (2006) An overview of the classification and evolution of the major scarab beetle clades (Coleoptera: Scarabaeoidea) based on preliminary molecular analyses. Coleopterists Society Monograph, 5, 35-46.

Sole, C.L., Wirta, H., Forgie, S.A. \& Scholtz, C.H. (2011) Origin of Madagascan Scarabaeinidung beetles (Coleoptera: Scarabaeidae): dispersal from Africa. Insect Systematics and Evolution, 42, $29-40$.

Stanley, S.M. (1986) Earth and Life through Time, 1st edn. W.H. Freeman \& Company, New York, New York.

Stocsits, R.R., Letch, H., Hertel, J., Misof, B. \& Stadler, P.F. (2009) Accurate and efficient reconstruction of deep phylogenies from structured RNAs. Nucleic Acids Research, 37, 6184-6193.

Swofford, D.L. (2003) PAUP*: Phylogenetic Analysis Using Parsimony (* and Other Methods), Version 4. Sinauer Associates, Sunderland, Massachusetts.

Tillier, E.R.M. \& Collins, R.A. (1998) High apparent rate of simultaneous compensatory base-pair substitutions in ribosomal RNA. Genetics, 148, 1993-2002.

Townsend, T.M., Tolley, K.A., Glaw, F., Böhme, W. \& Vences, M. (2011) Eastward from Africa: palaeocurrent-mediated chameleon dispersal to the Seychelles islands. Biology Letters, 7, 225-228.

Trewick, S.A. (2000) Molecular evidence for dispersal rather than vicariance as the origin of flightless insect species on the 
Chatham Islands, New Zealand. Journal of Biogeography, 27, $1189-1200$.

Upchurch, P. (2008) Gondwanan break-up: legacies of a lost world? Trends in Ecology \& Evolution, 23, 229-236.

Van Bocxlaer, I.V., Roelants, K., Biju, S., Nagaraju, J. \& Bossuyt, F. (2006) Late Cretaceous vicariance in Gondwanan amphibians. PLoS ONE, 1, e74. DOI: 10.1371/ journal.pone. 0000074.

Vaurie, P. (1955) A revision of the genus Trox in North America (Coleoptera: Scarabaeidae). Bulletin of the American Museum of Natural History, 106, 1-90.

Vaurie, P. (1962) A revision of the genus Trox in South America (Coleoptera: Scarabaeidae). Bulletin of the American Museum of Natural History, 124, 105-167.

Voigt, O., Erpenbeck, D. \& Wörheide, G. (2008) Molecular evolution of rDNA in early Diverging Metazoa: first comparative analysis and phylogenetic application of complete SSU rRNA secondary structure. BMC Evolutionary Biology, 8, 69.

Wägele, J.W. \& Mayer, C. (2007) Visualizing differences in phylogenetic information content of alignments and distinction of three classes of long-branch effects. BMC Evolutionary Biology, 7, 147.

Woodburne, M.O. \& Case, J.A. (1996) Dispersal, vicariance, and the Late Cretaceous to early Tertiary land mammal biogeography from South America to Australia. Journal of Mammalian Evolution, 3, $121-161$.

Yoder, A.D. \& Nowak, M.D. (2006) Has vicariance or dispersal been the predominant biogeographic force in Madagascar? Only time will tell. Annual Review of Ecology Evolution and Systematics, 37, 405-431.

Zhou, L., Su, Y.C.F., Thomas, D.C. \& Saunders, R.M.K. (2012) 'Out-of-Africa' dispersal of tropical floras during the Miocene climatic optimum: evidence from Uvaria (Annonaceae). Journal of Biogeography, 39, 322-335.

Zidek, J. (2013) Checklist and bibliography of the Trogidae (Coleoptera: Scarabaeoidea). Insecta Mundi, 0314, 1-38.

Accepted 3 March 2014

First published online 21 May 2014 


\section{Supporting information}

Figure S1. Phylogeny of Trogidae inferred from the combined 16S, 28S domain 2 and $18 \mathrm{~S}$ (sequence-based aligned) dataset and implementing a conventional DNA model setup using MrBayes.

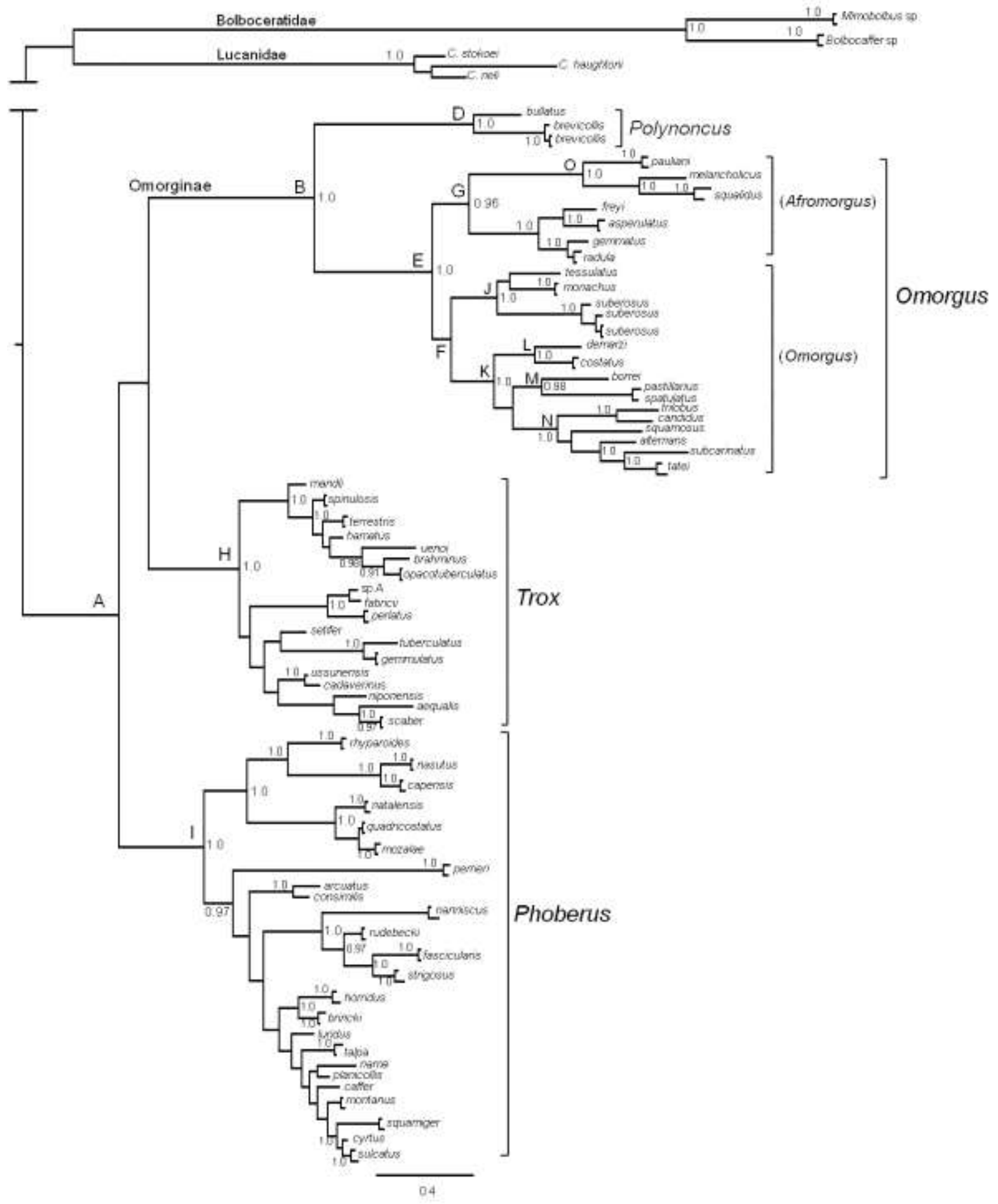


Figure S2. Phylogeny of Trogidae inferred from the combined 16S, $28 \mathrm{~S}$ domain 2 and $18 \mathrm{~S}$ (sequence-based aligned) dataset and implementing a mixed RNA/DNA (16-state RNA) model setup using MrBayes.
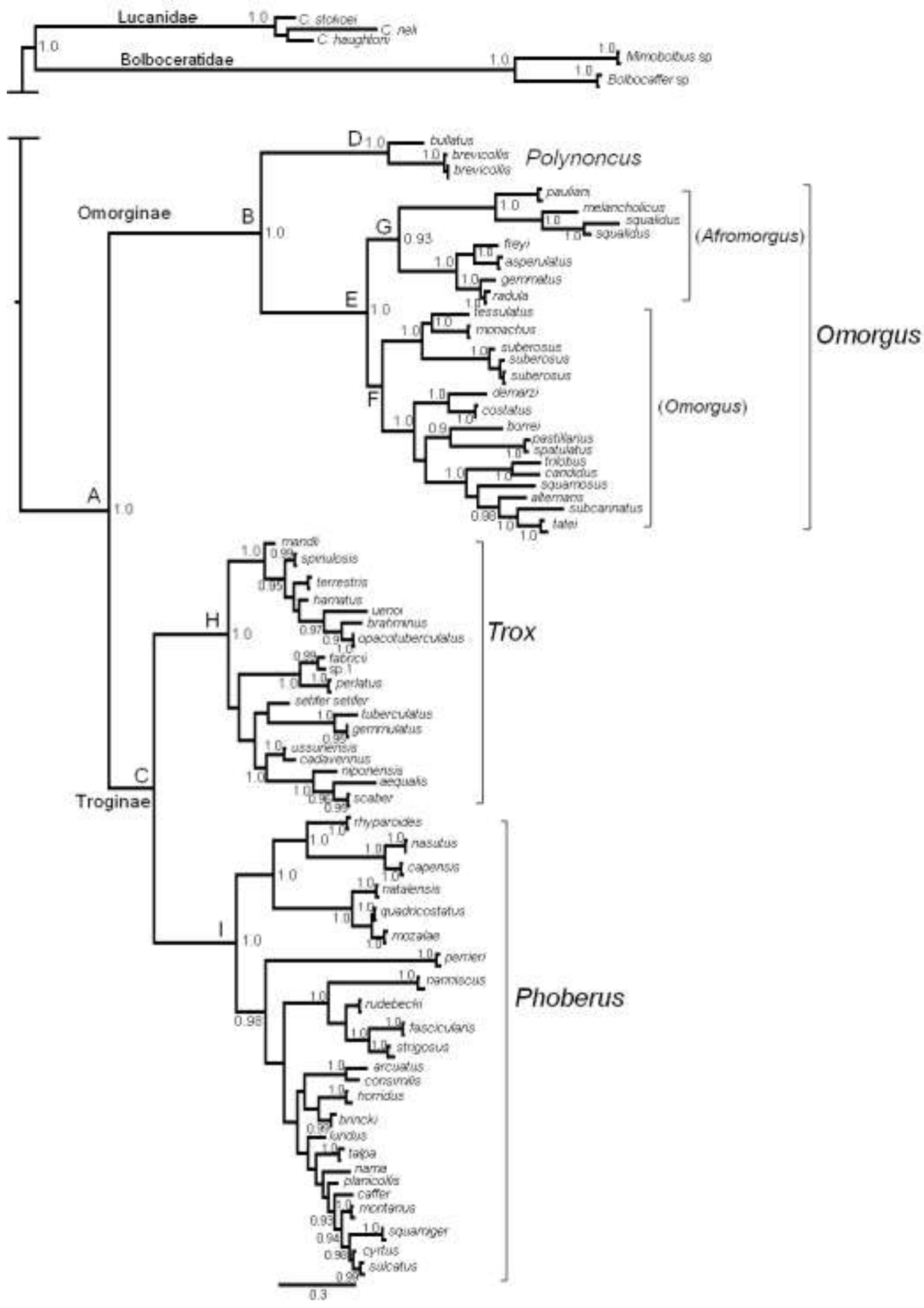
Table S1. List of taxa used in this study along with their GenBank accession numbers and locality data. X - Indicates PCR amplification failed.

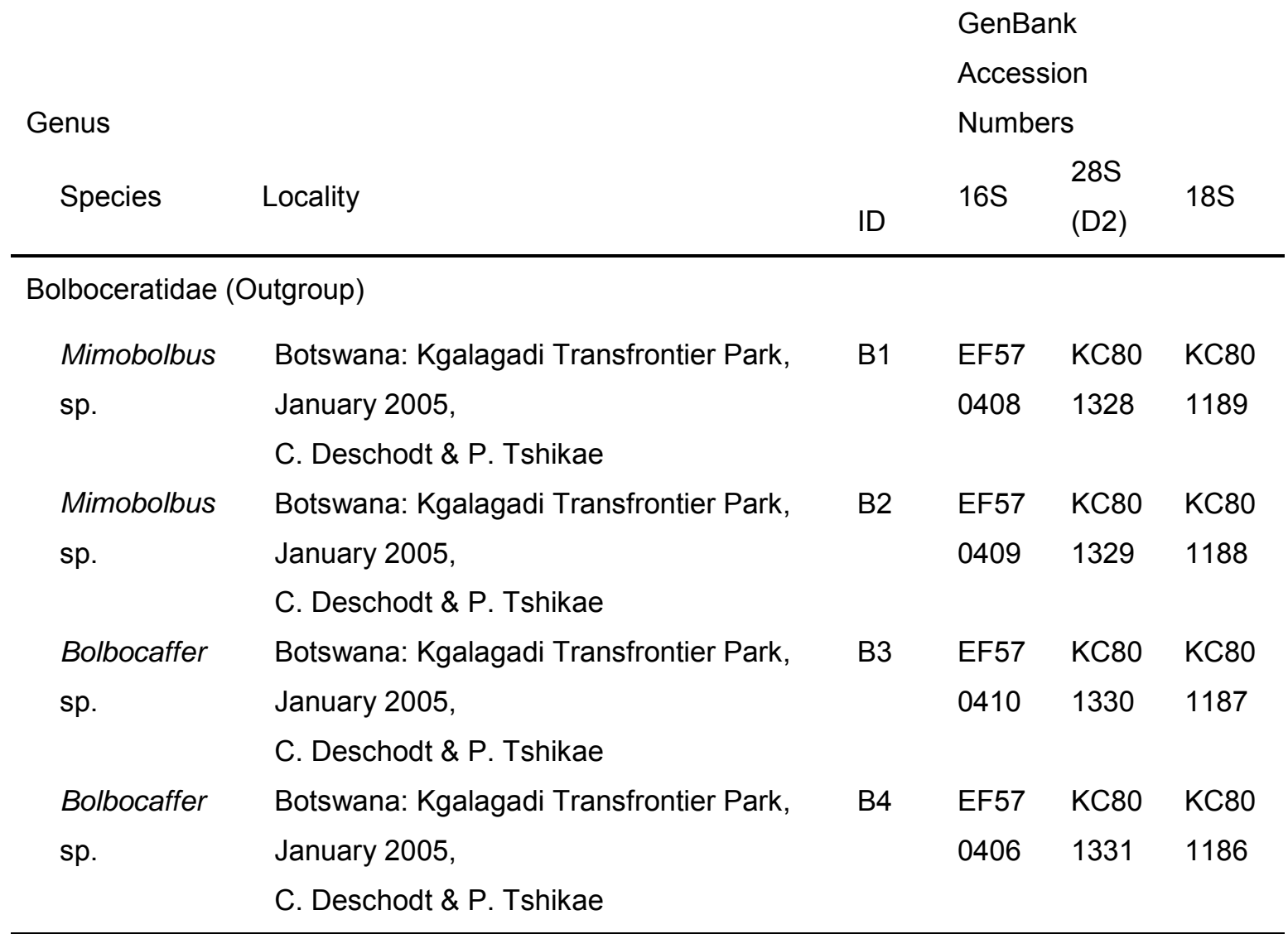

Lucanidae

(Outgroup)

Colophon neli

South Africa: Western Cape Prov.,

C1 KC76 KC80 KC80

Swartberg Mt. Range, January 2008, W.P.

$3267 \quad 1332 \quad 1232$

Strümpher \& C. Deschodt

C. haughtoni South Africa: Western Cape Prov.,

C2 $\quad \mathrm{KC76} \quad \mathrm{KC} 81 \quad \mathrm{KC} 80$

Hexriver Mountains, January, 2008, W.P.

$3256 \quad 0333 \quad 1233$

Strümpher \& C. Deschodt

C. stokoei South Africa: Western Cape Prov.,

C3 $\mathrm{KC76} \mathrm{KC} 80 \quad \mathrm{KC} 80$

Hottentots-Holand Mt. Range, December

$3248 \quad 1334 \quad 1234$

2007,W.P. Strümpher \& C. Deschodt

\begin{tabular}{ll}
\hline Polynoncus & \\
P. brevicollis & Chile: San Antonio; Aguas Buenas; \\
& 3.IX.1999; Leg. V. Manuel Dieguez M.
\end{tabular}

3A $\quad$ EF57 KC80 KC80

$0366 \quad 1325 \quad 1221$ 


\begin{tabular}{llllll} 
P. brevicollis & Chile: San Antonio; Aguas Buenas; & 3B & EF57 & KC80 & KC80 \\
& 3.IX.1999; Leg. V. Manuel Dieguez M. & & 0373 & 1326 & 1220 \\
P. brevicollis & Chile: San Antonio; Aguas Buenas; & 3C & EF57 & X & X \\
& 3.IX.1999; Leg. V. Manuel Dieguez M. & & 0385 & & \\
P. bullatus & Chile: Curico; Rauco-fundo La Pancora; & 1 & EF57 & KC80 & KC80 \\
& 31.VII.1999; Leg. V. Manuel Dieguez M. & & 0378 & 1327 & 1222 \\
\hline
\end{tabular}

Omorgus

(Omorgus)

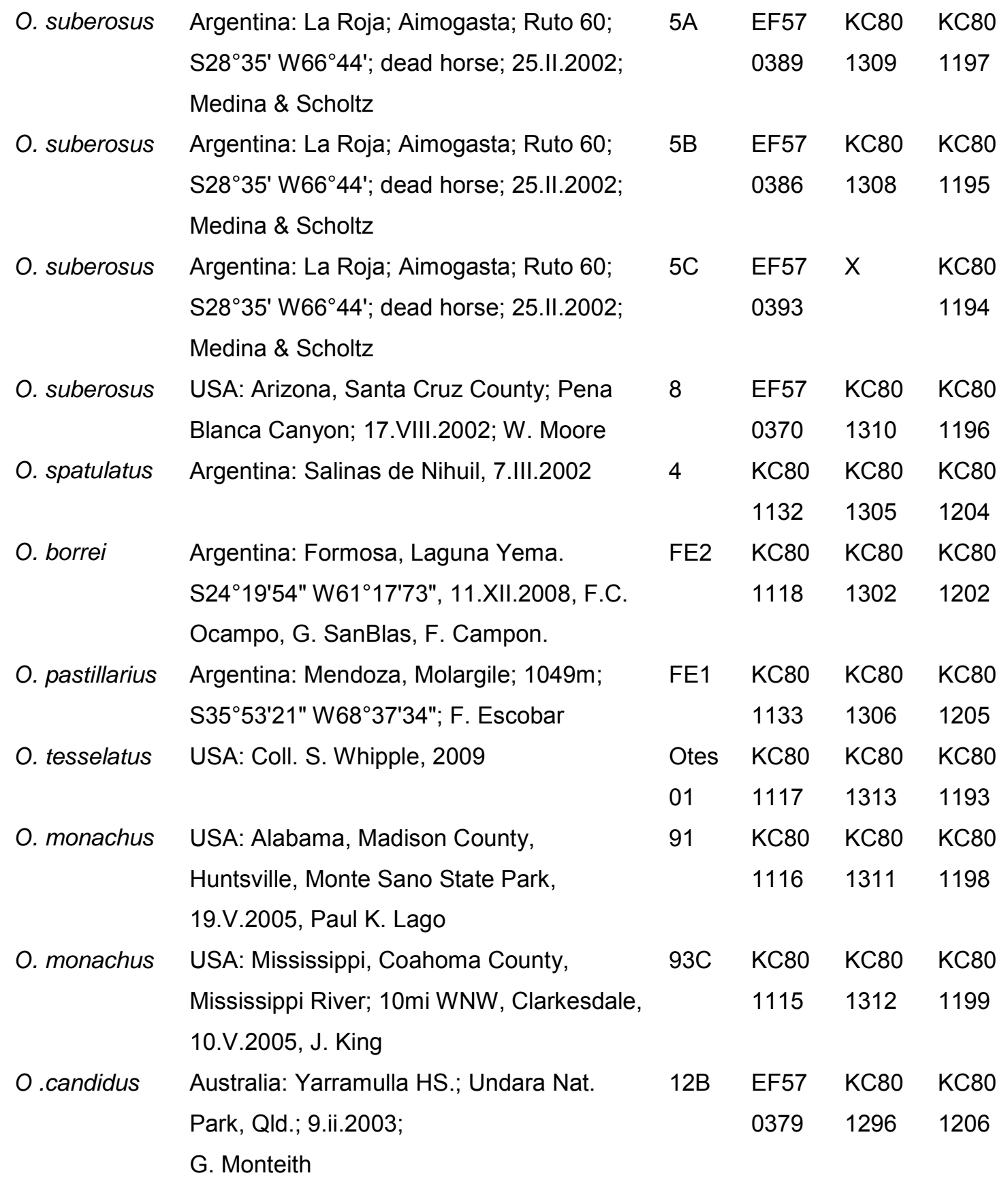




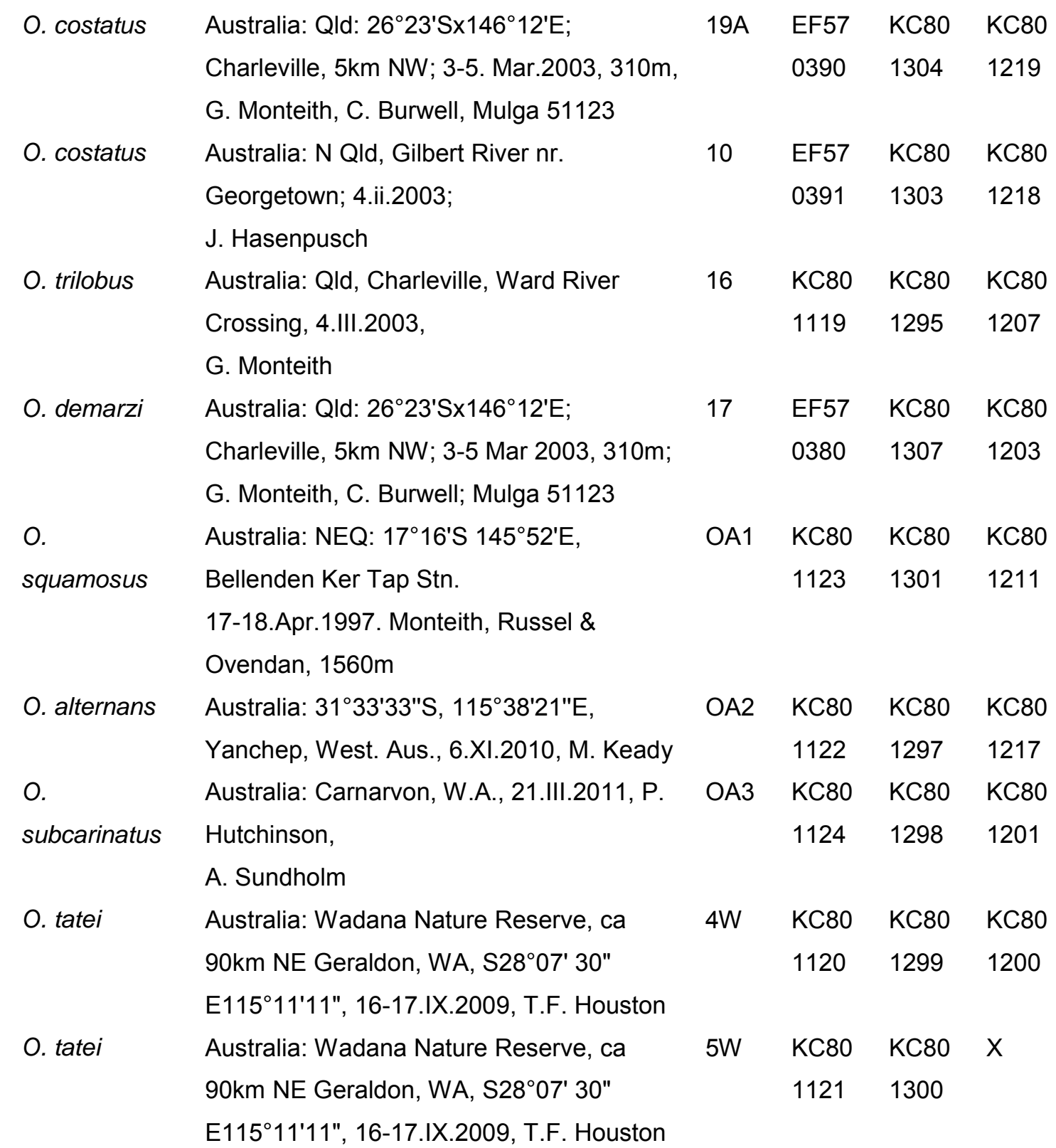

\section{Afromorgus}

\begin{tabular}{|c|c|c|c|c|c|}
\hline \multirow[t]{2}{*}{ A. pauliani } & Laos: Vientiane Nat. University Campus, & $1 \mathrm{~W}$ & KC80 & KC80 & KC80 \\
\hline & $\begin{array}{l}18^{\circ} 2,534^{\prime \prime} \mathrm{N} 102^{\circ} 37.768^{\prime \prime E}, 2-5 . V I .2008 \\
\text { leg. S. Tarasov }\end{array}$ & & 1127 & 1323 & 1214 \\
\hline \multirow[t]{2}{*}{ A. pauliani } & Laos: Vientiane Nat. University Campus, & $2 \mathrm{~W}$ & KC80 & KC80 & KC80 \\
\hline & $\begin{array}{l}18^{\circ} 2,534^{\prime \prime} \mathrm{N} 102^{\circ} 37.768^{\prime \prime E}, 2-5 . V I .2008, \\
\text { leg. S. Tarasov }\end{array}$ & & 1128 & 1324 & 1213 \\
\hline \multirow[t]{2}{*}{ A. gemmatus } & Senegal: Mbour, VIII.1995 & Oge & KC80 & KC80 & KC80 \\
\hline & & $\mathrm{m} 01$ & 1131 & 1319 & 1209 \\
\hline
\end{tabular}




\begin{tabular}{|c|c|c|c|c|c|}
\hline \multirow[t]{3}{*}{ A. squalidus } & South Africa: Kgalagadi Transfrontier Park; & $73 \mathrm{~A}$ & EF57 & KC80 & KC80 \\
\hline & S26²4'29.4" E2042'32.7", 913m; P. & & 0407 & 1320 & 1215 \\
\hline & Tshikae & & & & \\
\hline \multirow[t]{3}{*}{ A. squalidus } & South Africa: Freestate Prov., Ladybrand, & Oms & KC80 & KC80 & KC80 \\
\hline & $1700 \mathrm{~m}, 24 . \mathrm{X} .2007, \mathrm{~s} 29.14971^{\circ}$ & q01 & 1125 & 1321 & 1216 \\
\hline & E27.40688 ${ }^{\circ}$,WP Strümpher & & & & \\
\hline$A$. & Botswana: Nossob Camp; Kalahari & 31 & EF57 & KC80 & KC80 \\
\hline asperulatus & Gemsbok Park; 25.I.2003 & & 0412 & 1315 & 1190 \\
\hline A. & Botswana: Kgalagadi Transfrontier Park; & $102 \mathrm{~A}$ & EF57 & KC80 & KC80 \\
\hline \multirow[t]{2}{*}{ asperulatus } & S26²4' 29.4" E2042'32.7"; 913m; P. & & 0411 & 1314 & 1191 \\
\hline & Tshikae & & & & \\
\hline \multirow[t]{2}{*}{ A. radula } & South Africa: Kruger National Park, & $38 \mathrm{~A}$ & EF57 & KC80 & KC80 \\
\hline & Skukuza Camp, 12.II.2003 & & 0387 & 1318 & 1210 \\
\hline \multirow[t]{2}{*}{ A. radula } & Botswana: North Central Kalahari, P. & 105 & KC80 & KC80 & KC80 \\
\hline & Tshikae & & 1130 & 1317 & 1208 \\
\hline A. & South Africa: KwaZulu-Natal, Ndumu & $49 \mathrm{~A}$ & KC80 & KC80 & KC80 \\
\hline melancholicus & Game Reserve, XI. 2002, J. Harrison & & 1126 & 1322 & 1212 \\
\hline \multirow[t]{2}{*}{ A. freyi } & Botswana: Kalahari Gemsbok Park, & 27 & KC80 & KC80 & KC80 \\
\hline & Nossob Camp, 25.i.2003 & & 1129 & 1316 & 1192 \\
\hline \multicolumn{6}{|l|}{$\operatorname{rox}(\operatorname{Trox})$} \\
\hline \multirow[t]{2}{*}{ T. terrestris } & USA: Florida, Archbold, Biol. Stat., nr L. & $7 A$ & EF57 & KC80 & KC80 \\
\hline & Placid; 22-23.xi.2002; V. Grebennikov & & 0383 & 1283 & 1171 \\
\hline \multirow[t]{2}{*}{ T. terrestris } & USA: Florida, Archbold, Biol. Stat., nr L. & 7B & EF57 & KC80 & KC80 \\
\hline & Placid; 22-23.xi.2002; V. Grebennikov & & 0394 & 1282 & 1168 \\
\hline$T$. & Mexico: Chihauhau; Creel, 11.VII.2002; W. & $9 \mathrm{~A}$ & EF57 & KC80 & KC80 \\
\hline gemmulatus & Moore & & 0363 & 1290 & 1175 \\
\hline$T$. & Mexico: Chihauhau; Creel, 11.VII.2002; W. & $9 \mathrm{~B}$ & EF57 & KC80 & KC80 \\
\hline gemmulatus & Moore & & 0359 & 1291 & 1174 \\
\hline \multirow[t]{3}{*}{ T. aequalis } & USA: : Alabama; Madison County; & 90 & EF57 & $\mathrm{X}$ & KC80 \\
\hline & Huntsville; Monte Sano State Park; & & 0375 & & 1181 \\
\hline & 21.V.2005; Paul K. Lago & & & & \\
\hline \multirow[t]{2}{*}{ T. hamatus } & USA: New Jersey; Somerset Co.; & $83 B$ & EF57 & KB80 & KC80 \\
\hline & $\begin{array}{l}\text { Hutcheson Memorial Forest; 3-5.VIII.2004; } \\
\text { pitfall w/ dog faeces }\end{array}$ & & 0381 & 1278 & 1169 \\
\hline$T$ & USA: Mississippi; Coahoma County; & 95 & EF57 & KC80 & KC80 \\
\hline tuberculatus & $\begin{array}{l}\text { Mississippi River; 10mi WNW Clarksdale; } \\
\text { 10.V.2005; Jonas King }\end{array}$ & & 0364 & 1292 & 1173 \\
\hline
\end{tabular}




\begin{tabular}{|c|c|c|c|c|c|}
\hline \multirow[t]{2}{*}{ T. spinulosis } & USA: Mississippi; Coahoma County; & $96 \mathrm{~A}$ & EF57 & KC80 & KC80 \\
\hline & $\begin{array}{l}\text { Mississippi River; 10mi WNW Clarksdale; } \\
\text { 10.V.2005; Jonas King }\end{array}$ & & 0362 & 1279 & 1170 \\
\hline \multirow[t]{2}{*}{ T. spinulosis } & USA: Mississippi; Coahoma County; & $96 \mathrm{~B}$ & EF57 & KC80 & KC80 \\
\hline & $\begin{array}{l}\text { Mississippi River; 10mi WNW Clarksdale; } \\
\text { 10.V.2005; Jonas King }\end{array}$ & & 0376 & 1280 & 1172 \\
\hline \multirow[t]{2}{*}{ T. fabricii } & Greece: Naroc - Nassa, 15.III.2011, O. & Tfab & KC80 & KC80 & KC80 \\
\hline & Boilly & & 1110 & 1293 & 1184 \\
\hline \multirow{2}{*}{ T. scaber } & UK: Great Britain, Oxford & $\mathrm{TSc} 0$ & KC80 & KC80 & KC80 \\
\hline & & 1 & 1114 & 1288 & 1179 \\
\hline \multirow[t]{2}{*}{ T. scaber } & UK: Great Britain, Oxford & $\mathrm{TSc0}$ & KC80 & KC80 & KC80 \\
\hline & & 2 & 1113 & 1287 & 1182 \\
\hline T. perlatus & $\begin{array}{l}\text { Spain: Andalusia Camping Torre del Oro } \\
\text { (ca } 25 \mathrm{~km} \text { SE Huelva); } 37^{\circ} 05^{\prime} 41.9^{\prime \prime} \mathrm{N} \\
06^{\circ} 43^{\prime} 44.1^{\prime \prime W} \text {; } 18 . V .2006 \text {; D. Ahrens \& S. } \\
\text { Fabrizi }\end{array}$ & TpE1 & $\begin{array}{l}\text { KC80 } \\
1111\end{array}$ & $\begin{array}{l}\text { KC80 } \\
1294\end{array}$ & $\begin{array}{l}\text { KC80 } \\
1185\end{array}$ \\
\hline T. perlatus & $\begin{array}{l}\text { Spain: Andalusia Camping Torre del Oro } \\
\text { (ca } 25 \mathrm{~km} \text { SE Huelva); } 37^{\circ} 05^{\prime} 41.9^{\prime \prime} \mathrm{N} \\
06^{\circ} 43^{\prime} 44.1 " \mathrm{~W} ; 18 . V .2006 \text {; D. Ahrens \& S. } \\
\text { Fabrizi }\end{array}$ & TpE2 & $\begin{array}{l}\text { KC80 } \\
1112\end{array}$ & $x$ & $\begin{array}{l}\text { KC80 } \\
1183\end{array}$ \\
\hline T. brahminus & $\begin{array}{l}\text { Laos: Bolaven Plateau, Bam. Thongray, } \\
15^{\circ} 14.054^{\prime} \mathrm{N} 106^{\circ} 31.8677^{\prime} \mathrm{E}, 1000 \mathrm{~m}, 8- \\
\text { 16.VI.2008, S. Tarasov }\end{array}$ & TbA1 & $\begin{array}{l}\text { KC80 } \\
1106\end{array}$ & $\begin{array}{l}\text { KC80 } \\
1275\end{array}$ & $\begin{array}{l}\text { KC80 } \\
1167\end{array}$ \\
\hline$T$. & China: Mt.Zheng-nan-gou, Wuchang City, & Tcad & KC80 & KC80 & KC80 \\
\hline cadaverinus & $\begin{array}{l}\text { Heilongjiang, } \\
\text { 1-11.VI.2011, Li Jingke }\end{array}$ & 01 & 1108 & 1285 & 1178 \\
\hline T. mandli & $\begin{array}{l}\text { China: Mt.Zheng-nan-gou, Wuchang City, } \\
\text { Heilongjiang, } \\
\text { 1-11.VI.2011, Li Jingke }\end{array}$ & Tdo & $\begin{array}{l}\text { KC80 } \\
1107\end{array}$ & $\begin{array}{l}\text { KC80 } \\
1281\end{array}$ & $x$ \\
\hline T. niponensis & $\begin{array}{l}\text { Japan: Nara-ken; Kamikitayama-mura; Mt. } \\
\text { Wasamatayama; 5.VI.2005; Satoru Nu leg. }\end{array}$ & 100 & $\begin{array}{l}\text { EF57 } \\
0413\end{array}$ & $\begin{array}{l}\text { KC80 } \\
1289\end{array}$ & $\begin{array}{l}\text { KC80 } \\
1180\end{array}$ \\
\hline$T$. & Japan: Nara-ken; Kamikitayama-mura; Mt. & $101 \mathrm{~A}$ & EF57 & KC80 & KC80 \\
\hline $\begin{array}{l}\text { opacotubercul } \\
\text { atus }\end{array}$ & Wasamatayama; 5.VI.2005; Satoru Nu leg. & & 0382 & 1277 & 1165 \\
\hline$T$. & Japan: Nara-ken; Kamikitayama-mura; Mt. & $101 \mathrm{~B}$ & EF57 & KC80 & KC80 \\
\hline $\begin{array}{l}\text { opacotubercul } \\
\text { atus }\end{array}$ & Wasamatayama; 5.VI.2005; Satoru Nu leg. & & 0368 & 1276 & 1166 \\
\hline
\end{tabular}




\begin{tabular}{|c|c|c|c|c|c|}
\hline \multirow[t]{3}{*}{ T. ussuriensis } & China: Mt.Zheng-nan-gou, Wuchang City, & Tuss & KC80 & KC80 & KC80 \\
\hline & Heilongjiang, & 01 & 1109 & 1284 & 1177 \\
\hline & 1-11.VI.2011, Li Jingke & & & & \\
\hline \multirow{2}{*}{$\begin{array}{l}\text { T. setifer } \\
\text { setifer }\end{array}$} & Japan: Nara-ken; Kamikitayama-mura; Mt. & 99 & EF57 & KC80 & KC80 \\
\hline & Wasamatayama; 5.VI.2005; Satoru Nu leg. & & 0365 & 1286 & 1176 \\
\hline \multirow[t]{2}{*}{ T. perrieri } & Madagascar: La Mandraka, 16.I.2007, & Tpro & KC80 & KC80 & KC80 \\
\hline & Olivier Boilly & 2 & 1098 & 1273 & 1223 \\
\hline \multirow[t]{2}{*}{ T. perrieri } & Madagascar: La Mandraka, 16.I.2007, & Tpro & KC80 & KC80 & $x$ \\
\hline & Olivier Boilly & 3 & 1099 & 1274 & \\
\hline \multicolumn{6}{|l|}{ Trox (Phoberus) } \\
\hline \multirow[t]{3}{*}{ T. horridus } & South Africa: Western Cape Prov., & ThG & KC80 & KC80 & KC80 \\
\hline & Gansekraal, 05.IX.2008, S33.52562 & $\mathrm{k} 02$ & 1083 & 1243 & 1164 \\
\hline & E18.32054 ; 20m, C. Deschodt & & & & \\
\hline \multirow[t]{3}{*}{ T. horridus } & South Africa: Western Cape Prov., & ThG & KC80 & KC80 & KC80 \\
\hline & Gansekraal, 05.IX.2008, S33.52562 ${ }^{\circ}$ & k06 & 1084 & 1244 & 1163 \\
\hline & E18.32054; 20m, C. Deschodt & & & & \\
\hline \multirow[t]{3}{*}{ T. brincki } & Lesotho: Mokhotlong District, 19.X.2007, & TbL0 & KC80 & KC80 & KC80 \\
\hline & $\mathrm{S} 29^{\circ} 31^{\prime} 6.60^{\prime \prime}$ & 2 & 1079 & 1241 & 1140 \\
\hline & E29¹1'12.99", 3089m, WP. Strümpher & & & & \\
\hline \multirow[t]{3}{*}{ T. brincki } & Lesotho: Mokhotlong District, 19.X.2007, & TbL0 & KC80 & KC80 & KC80 \\
\hline & $\mathrm{S} 29^{\circ} 31^{\prime} 6.60^{\prime \prime}$ & 4 & 1080 & 1242 & 1141 \\
\hline & E29¹1'12.99", 3089m, WP. Strümpher & & & & \\
\hline \multirow[t]{3}{*}{ T. nasutus } & South Africa: Western Cape Prov., near & TnS & KC80 & KC80 & KC80 \\
\hline & Simonstown, 07.IX.2008, S34.22200 & T01 & 1097 & 1270 & 1228 \\
\hline & E18.41069, $80 \mathrm{~m}$, C. Deschodt & & & & \\
\hline \multirow[t]{3}{*}{ T. nasutus } & South Africa: Western Cape Prov., near & TnS & KC80 & KC80 & KC80 \\
\hline & Simonstown, 07.IX.2008, S34.22200 & T02 & 1096 & 1269 & 1229 \\
\hline & E18.41069º, 80m, C. Deschodt & & & & \\
\hline \multirow[t]{2}{*}{ T. capensis } & South Africa: Western Cape Prov., & CMK & KC80 & KC80 & KC80 \\
\hline & 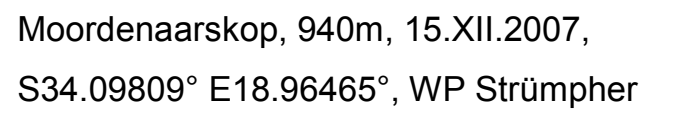 & 05 & 1095 & 1271 & 1224 \\
\hline \multirow[t]{2}{*}{ T. capensis } & South Africa: Western Cape Prov., & $\operatorname{csn}$ & $\mathrm{KC} 80$ & $\mathrm{KC} 80$ & KC80 \\
\hline & $\begin{array}{l}\text { Sneeukop, S34.03919 E18.99026, } \\
\text { 1300m, 18.XII.2007, WP. Strümpher }\end{array}$ & 03 & 1094 & 1272 & 1225 \\
\hline
\end{tabular}




\begin{tabular}{|c|c|c|c|c|c|}
\hline T. natalensis & South Africa: KZN, Durban, 16.XI.2008, & $\mathrm{TnD}$ & KC80 & KC80 & KC80 \\
\hline & S295'ㄷ․13" E3056'9.13", WP. & 01 & 1101 & 1263 & 1147 \\
\hline & Strümpher & & & & \\
\hline T. natalensis & South Africa: KZN, Durban, 16.XI.2008, & $\mathrm{TnD}$ & KC80 & KC80 & KC80 \\
\hline & S295'ㄷ․13" E3056'9.13", WP. & 04 & 1100 & 1264 & 1146 \\
\hline & Strümpher & & & & \\
\hline$T$ & South Africa: KZN, Ndumu Game Reserve, & Tq01 & KC80 & KC80 & KC80 \\
\hline quadricostatu & 2002.11.01, & & 1103 & 1261 & 1143 \\
\hline$s$ & J. Harrison & & & & \\
\hline$T$. & South Africa: KZN, Ndumu Game Reserve, & Tq02 & KC80 & KC80 & KC80 \\
\hline quadricostatu & 2002.11.01, & & 1102 & 1262 & 1144 \\
\hline$s$ & J. Harrison & & & & \\
\hline T. mozalae & Mozambique: Maputo Elephant Reserve. & $\mathrm{mme}$ & KC80 & KC80 & KC80 \\
\hline & 27.XI.2007, S26.51006 E32.91270', WP. & $\mathrm{r} 01$ & 1104 & 1265 & 1142 \\
\hline & Strümpher & & & & \\
\hline T. mozalae & Mozambique: Maputo Elephant Reserve. & mme & KC80 & KC80 & KC80 \\
\hline & 27.XI.2007, S26.51006 ${ }^{\circ} \mathrm{E} 32.91270^{\circ}, \mathrm{WP}$. & r02 & 1105 & 1266 & 1145 \\
\hline & Strümpher & & & & \\
\hline$T$. & South Africa: Eastern Cape Prov. & $70 \mathrm{~A}$ & EF57 & KC80 & KC80 \\
\hline rhyparoides & Baviaanskloof, Poortjies (Poort); U. Kryger; & & 0372 & 1267 & 1226 \\
\hline & 22.X-8.XI.2003 & & & & \\
\hline$T$. & South Africa: KZN, Ngome , A. Frolov, & $54 \mathrm{~A}$ & EF57 & KC80 & KC80 \\
\hline rhyparoides & 2003 & & 0402 & 1268 & 1227 \\
\hline T. montanus & Kenya: Aberdare N.P.; 30.X.2002- & $22 \mathrm{~A}$ & EF57 & KC80 & KC80 \\
\hline & 03.XI.2002; 3100m; Between Kiandongoro & & 0377 & 1238 & 1152 \\
\hline & \& Mutobio gates, V. Grebennikov & & & & \\
\hline T. montanus & Kenya: Aberdare N.P.; 30.X.2002- & 22B & EF57 & KC80 & KC80 \\
\hline & 03.XI.2002; 3100m; Between Kiandongoro & & 0371 & 1239 & 1153 \\
\hline & \& Mutobio gates, V. Grebennikov & & & & \\
\hline T. fascicularis & South Africa: Western Cape Prov., & ffSnO & KC80 & KC80 & KC80 \\
\hline & Sneeukop, S34.03919 E18.99026 & 3 & 1087 & 1256 & 1156 \\
\hline & 1300m, 18.XII.2007, WP. Strümpher & & & & \\
\hline T. fascicularis & South Africa: Western Cape Prov., & ffSnO & KC80 & KC80 & KC80 \\
\hline & Sneeukop, S34.03919 E18.99026 & 4 & 1088 & 1257 & 115 \\
\hline & 1300m, 18.XII.2007, WP. Strümpher & & & & \\
\hline
\end{tabular}




\begin{tabular}{|c|c|c|c|c|c|}
\hline \multirow[t]{3}{*}{ T. strigosus } & South Africa: Western Cape Prov., & Tstrg & KC80 & KC80 & KC80 \\
\hline & S31.48519 E23.73770, 19.1 .2008$, WP & 01 & 1086 & 1255 & 1157 \\
\hline & Strümpher & & & & \\
\hline \multirow[t]{3}{*}{ T. strigosus } & South Africa: Western Cape Prov., & Tstrg & KC80 & KC80 & KC80 \\
\hline & S31.48519 E23.73770 $, 19.1 .2008, W P$ & 02 & 1085 & 1254 & 1155 \\
\hline & Strümpher & & & & \\
\hline \multirow[t]{4}{*}{ T. nanniscus } & South Africa: Eastern Cape Prov., & Tnan & KC80 & KC80 & KC80 \\
\hline & Grahamstown, 635m, S3316'14.79" & 05 & 1093 & 1260 & 1230 \\
\hline & E26²8'46.03", 14-16.XI.2008, WP. & & & & \\
\hline & Strümpher & & & & \\
\hline \multirow[t]{4}{*}{ T. nanniscus } & South Africa: Eastern Cape Prov., & Tnan & KC80 & KC80 & KC80 \\
\hline & Grahamstown, 635m, S33¹6'14.79" & 06 & 1092 & 1259 & 1231 \\
\hline & E26²8'46.03", 14-16.XI.2008, WP. & & & & \\
\hline & Strümpher & & & & \\
\hline \multirow[t]{3}{*}{ T. rudebecki } & Lesotho: Sani Top, 2880m, 19.X.2007, & RL01 & KC80 & KC80 & KC80 \\
\hline & $29^{\circ} 34^{\prime} 43.12^{\prime \prime S} 29^{\circ} 16^{\prime} 50.75^{\prime \prime E}, W P$. & & 1089 & 1258 & 1158 \\
\hline & Strümpher & & & & \\
\hline \multirow[t]{3}{*}{ T. rudebecki } & Lesotho: Sani Top, 2880m, 19.X.2007, & RL25 & KC80 & $\mathrm{X}$ & KB80 \\
\hline & $29^{\circ} 34^{\prime} 43.12^{\prime \prime S} 29^{\circ} 16^{\prime} 50.75^{\prime \prime E}, W P$. & & 1090 & & 1159 \\
\hline & Strümpher & & & & \\
\hline \multirow[t]{2}{*}{ T. arcuatus } & South Africa: Western Cape Prov., & 69 & EF57 & KC80 & KC80 \\
\hline & $\begin{array}{l}\text { Kweekkraal farm; 9km west of Riversdale; } \\
\text { U. Kryger; 22.X-8.XI.2003 }\end{array}$ & & 0395 & 1249 & 1148 \\
\hline \multirow[t]{4}{*}{ T. consimilis } & South Africa: Northern Cape Prov., & Tcon & KC80 & KC80 & KC80 \\
\hline & S31¹2'26.74" Calvinia district, & 01 & 1091 & 1250 & 1149 \\
\hline & E1940'47.14", 838m, 29.VIII.2009, CH. & & & & \\
\hline & Scholtz & & & & \\
\hline \multirow[t]{2}{*}{ T. talpa } & South Africa: Western Cape Prov., & 68 & EF57 & KC80 & KC80 \\
\hline & $\begin{array}{l}\text { Kweekkraal farm; 9km west of Riversdale; } \\
\text { U. Kryger; 22.X-8.XI.2003 }\end{array}$ & & 0400 & 1248 & 1135 \\
\hline \multirow[t]{3}{*}{ T. talpa } & South Africa: Freestate Prov., Ladybrand, & Tt02 & KC80 & KC80 & KC80 \\
\hline & $1700 \mathrm{~m}, 24 . X .2007, \mathrm{~S} 29.14971^{\circ}$ & & 1081 & 1247 & 1134 \\
\hline & E27.40688 ${ }^{\circ}$, WP. Strümpher & & & & \\
\hline \multirow[t]{2}{*}{ T. sulcatus } & South Africa: Freestate Prov., Parys, & 62 & 7 & 0 & KC80 \\
\hline & 13.X.2003, C.H. Scholtz & & 0397 & 1237 & 1160 \\
\hline
\end{tabular}




\begin{tabular}{|c|c|c|c|c|c|}
\hline \multirow[t]{3}{*}{ T. sulcatus } & South Africa: Eastern Cape Prov., & 66 & EF57 & KC80 & KC80 \\
\hline & Willowmore; Timbi 2; & & 0398 & 1235 & 1162 \\
\hline & U. Kryger; 22.X-8.XI.2003 & & & & \\
\hline \multirow[t]{3}{*}{ T. squamiger } & South Africa: Freestate Prov., Ladybrand, & SqLO & KC80 & KC80 & KC80 \\
\hline & $1841 \mathrm{~m}, 30 . \mathrm{X} .2007, \mathrm{~S} 29.14971^{\circ}$ & 8 & 1078 & 1252 & 1151 \\
\hline & E27.40688 ${ }^{\circ}$, WP. Strümpher & & & & \\
\hline \multirow[t]{3}{*}{ T. squamiger } & South Africa: Freestate Prov., Ladybrand, & SqLO & KC80 & KC80 & KC80 \\
\hline & $1841 \mathrm{~m}, 30 . \mathrm{X} .2007, \mathrm{~S} 29.14971^{\circ}$ & 2 & 1077 & 1251 & 1150 \\
\hline & E27.40688 ${ }^{\circ}$, WP. Strümpher & & & & \\
\hline \multirow[t]{3}{*}{ T. nama } & Namibia; Boom River, canyon ca.10km of & $25 \mathrm{~A}$ & EF57 & KC80 & KC80 \\
\hline & estuary; A. Frolov leg.; 30-31.III.2003; & & 0403 & 1253 & 1139 \\
\hline & S2755'28.3" E1701'14.6"; 590m & & & & \\
\hline \multirow[t]{2}{*}{ T. caffer } & South Africa: Northern Cape Prov., nr. & Tcaf & KC80 & KC80 & KC80 \\
\hline & $\begin{array}{l}\text { Hanover, S30.99228 }{ }^{\circ} \text { E24.50198 }{ }^{\circ}, 1396 \mathrm{~m} \text {, } \\
\text { 10.III.2008. WP. Strümpher }\end{array}$ & 01 & 1076 & 1240 & 1137 \\
\hline \multirow[t]{4}{*}{ T. cyrtus } & South Africa: Northern Cape Prov., & $67 \mathrm{~B}$ & EF57 & KC80 & KC80 \\
\hline & Kamieskroon, A. Frolov, & & 0384 & 1236 & 1161 \\
\hline & C. Deschodt, 1-13.IX.2003; S30¹5'58" E & & & & \\
\hline & $17^{\circ} 55^{\prime} 30^{\prime \prime}$ & & & & \\
\hline \multirow[t]{3}{*}{ T. planicollis } & South Africa: Northern Cape Prov., & Tpla & KC80 & KC80 & KC80 \\
\hline & S31'12'26.74" E1940'47.14", & $\mathrm{n} 01$ & 1075 & 1246 & 1138 \\
\hline & 29.VIII.2009. CH. Scholtz & & & & \\
\hline \multirow[t]{3}{*}{ T. luridus } & South Africa: Western Cape Prov., & Tlur0 & KC80 & KC80 & KC80 \\
\hline & Vanrhynsdorp, S3132'0" E18²4'12", & 1 & 1082 & 1245 & 1136 \\
\hline & 05.VIII.2008, CH. Scholtz \& WP Strümpher & & & & \\
\hline
\end{tabular}


Table S2. Summary of oligonucleotide primers used in this study.

\begin{tabular}{lllll}
\hline Gene & Primer & Direction & Primer sequence $\left(5^{\prime} \rightarrow 3^{\prime}\right)$ & Reference \\
\hline 16S & 16sf (luisa) & forward & atgtcttttgakwataatwtaaag & Orsini et al. (2007) \\
& 16sr (luisa) & reverse & acgctgttatccctaaggtaattt & Orsini et al. (2007) \\
$18 S$ & 18s-intfw-st12 & forward & atcaagaacgaaagttagag & Haring \& Aspöck (2004) \\
& 18s-rev1 & reverse & atggggaacaattgcaagc & Haring \& Aspöck (2004) \\
28 (D2) & D2-3551 & forward & cgtgttgcttgatagtgcagc & Gillespie et al. (2005) \\
& D2-4057 & reverse & tcaagacgggtcctgaaagt & Gillespie et al. (2005) \\
& Wer-F1 & forward & taagygggtggtaaactc & This study \\
& Wer-R1 & reverse & tatagcgtcgcygacgggcg & This study \\
\hline
\end{tabular}


Table S3. PCR thermal cycling profiles.

\begin{tabular}{|c|c|c|c|c|c|c|}
\hline \multirow[b]{2}{*}{ Gene } & \multirow{2}{*}{$\begin{array}{l}\text { Stage } 1 \\
\text { Initial } \\
\text { denaturation }\end{array}$} & \multicolumn{4}{|c|}{ Stage 2 - Thermal cycling } & \multirow{2}{*}{$\begin{array}{l}\text { Stage } 3 \\
\text { Final } \\
\text { elongation }\end{array}$} \\
\hline & & $\begin{array}{c}\# \\
\text { Cycles }\end{array}$ & Denaturation & Annealing & Elongation & \\
\hline $16 S$ & $94^{\circ} \mathrm{C}-90 \mathrm{sec}$ & 35 & $\begin{array}{l}\left(94^{\circ} \mathrm{C}-\right. \\
60 \mathrm{sec},\end{array}$ & $\begin{array}{l}48^{\circ} \mathrm{C}- \\
90 \mathrm{sec}\end{array}$ & $\begin{array}{l}72^{\circ} \mathrm{C}- \\
90 \mathrm{sec})\end{array}$ & $72^{\circ} \mathrm{C}-1 \mathrm{~min}$ \\
\hline $18 S$ & $95^{\circ} \mathrm{C}-2 \mathrm{~min}$ & 30 & $\begin{array}{l}\left(95^{\circ} \mathrm{C}-\right. \\
10 \mathrm{sec}\end{array}$ & $\begin{array}{l}48^{\circ} \mathrm{C}- \\
10 \mathrm{sec}\end{array}$ & $\begin{array}{l}72^{\circ} \mathrm{C}- \\
90 \mathrm{sec})\end{array}$ & $72^{\circ} \mathrm{C}-5 \mathrm{~min}$ \\
\hline 28S(D2) & $96^{\circ} \mathrm{C}-20 \mathrm{sec}$ & 30 & $\begin{array}{l}\left(96^{\circ} \mathrm{C}-\right. \\
15 \mathrm{sec},\end{array}$ & $\begin{array}{l}60^{\circ} \mathrm{C}- \\
20 \mathrm{sec}\end{array}$ & $\begin{array}{l}72^{\circ} \mathrm{C}- \\
60 \mathrm{sec})\end{array}$ & $72^{\circ} \mathrm{C}-1 \mathrm{~min}$ \\
\hline
\end{tabular}


Table S4. Data characteristics and estimated model parameters for 16S, $28 \mathrm{~S}$ domain 2, $18 \mathrm{~S}$ and

\begin{tabular}{|c|c|c|c|c|}
\hline & \\
\hline & $16 S$ & 28S D2 & $18 S$ & Combined \\
\hline Number of samples & 107 & 100 & 101 & 107 \\
\hline Aligned positions & 405 & 601 & 562 & 1568 \\
\hline Paired characters $(\%)$ & $112(27.7)$ & $268(46.6)$ & $350(62.3)$ & $730(46.6)$ \\
\hline Unpaired characters (\%) & $293(72.3)$ & $333(55.4)$ & $212(37.7)$ & $838(53.4)$ \\
\hline $\begin{array}{l}\text { Parsimony informative } \\
\text { sites }\end{array}$ & 168 & 215 & 38 & 421 \\
\hline Tree length (MP) & 918 & $676^{*}$ & 79 & 1779 \\
\hline Number of tree (MP) & 10951 & $889^{*}$ & 208147 & 49 \\
\hline $\mathrm{Cl} / \mathrm{RI}(\mathrm{MP})$ & $0.300 / 0.770$ & $0.491 / 0.862^{*}$ & $0.620 / 0.942$ & $0.381 / 0.840$ \\
\hline Best fit model (AIC) & $G T R+G$ & $\mathrm{GTR}+\mathrm{G}$ & $K 80+1+G$ & $G T R+G$ \\
\hline A frequency & 0.3555 & 0.2083 & 0.2134 & 0.7826 \\
\hline C frequency & 0.814 & 0.3105 & 0.2622 & 0.2265 \\
\hline G frequency & 0.1346 & 0.3144 & 0.3037 & 0.2555 \\
\hline$T$ frequency & 0.4284 & 0.1669 & 0.2206 & 0.2635 \\
\hline Gamma (G) & 0.2040 & 0.2610 & 0.1460 & 0.1500 \\
\hline Invariable sites (I) & 0 & 0 & 0.5600 & 0 \\
\hline
\end{tabular}

